\title{
Yessotoxins, a Group of Marine Polyether Toxins: an Overview
}

\author{
Beatriz Paz ${ }^{1, *}$, Antonio H. Daranas ${ }^{2,3}$, Manuel Norte ${ }^{2}$, Pilar Riobó ${ }^{1}$, José M. Franco ${ }^{1}$ and \\ José J. Fernández ${ }^{2, *}$
}

1 Fitoplancton Tóxico, Instituto de Investigaciones Marinas (CSIC), Eduardo Cabello 6, 36080 Vigo and Instituto Español de Oceanografía, Centro Oceanográfico de Vigo (IEO), Cabo Estay, 36200 Vigo, Spain. E-mails: beatriz.paz@vi.ieo.es (B. Paz); pilar.riobo@vi.ieo.es (P. Riobó); jose.franco@vi.ieo.es (J.M. Franco)

2 Instituto Universitario de Bio-Orgánica "Antonio González", Universidad de La Laguna, Astrofísico Francisco Sánchez 2, 38206 La Laguna, Tenerife, Spain. E-mails: adaranas@ull.es (A. Daranas); mnorte@ull.es (M. Norte); jjfercas@ull.es (J.J. Fernández)

3 Departamento de Ingeniería Química y Tecnología Farmacéutica; Universidad de La Laguna; Av. Astrofísico Francisco Sánchez s/n, 38071, La Laguna, Tenerife, Spain

* Author to whom correspondence should be addressed. Tel: +34986492111; Fax: +34986498626

(B. Paz) and Tel: +34922318586; Fax: +34922318571 (J.J. Fernández)

Received: 5 December 2007; in revised form: 27 February 2008 / Accepted: 5 March 2008 / Published: 7 May 2008

\begin{abstract}
Yessotoxin (YTX) is a marine polyether toxin that was first isolated in 1986 from the scallop Patinopecten yessoensis. Subsequently, it was reported that YTX is produced by the dinoflagellates Protoceratium reticulatum, Lingulodinium polyedrum and Gonyaulax spinifera. YTXs have been associated with diarrhetic shellfish poisoning (DSP) because they are often simultaneously extracted with DSP toxins, and give positive results when tested in the conventional mouse bioassay for DSP toxins. However, recent evidence suggests that YTXs should be excluded from the DSP toxins group, because unlike okadaic acid (OA) and dinophyisistoxin-1 (DTX-1), YTXs do not cause either diarrhea or inhibition of protein phosphatases. In spite of the increasing number of molecular studies focused on the toxicity of YTX, the precise mechanism of action is currently unknown. Since the discovery of YTX, almost forty new analogues isolated from both mussels and dinoflagellates have been characterized by NMR or LC-MS/MS techniques. These studies indicate a wide variability in the profile and the relative abundance of YTXs in both, bivalves and dinoflagellates. This review covers current knowledge on the origin, producer organisms and vectors, chemical structures, metabolism, biosynthetic origin, toxicological properties, potential risks to human health and advances in detection methods of YTXs.
\end{abstract}

Keywords: Yessotoxin (YTX), Diarrhetic Shellfish Poisoning (DSP), Marine polyether toxin, Protoceratium reticulatum, Lingulodinium polyedrum, Gonyaulax spinifera. 


\section{Introduction}

Microalgae are responsible for a large proportion of the photosynthetically produced biomass that supports zooplankton and other higher life forms. Filter-feeding organisms, such as bivalve shellfish and larvae of commercially important crustaceans rely almost completely on phytoplankton for food. Most mass proliferations of phytoplankton, known as algal blooms, are harmless and can actually benefit aquaculture and wild fisheries; however, under exceptional circumstances, high-density blooms can cause the indiscriminate death of fish and invertebrates through oxygen depletion, which in turn leads to economic losses and major environmental problems. In addition, certain microalgae produce toxic metabolites, which have an important impact on both human health and shellfish industries. Blooms of these toxic algae are known as Harmful Algal Blooms (HABs). At least 90 species of marine microalgae are known to produce toxins, of these, 70 are dinoflagellates [1].

Yessotoxins (YTXs) are a group of structurally related polyether toxins produced by the dinoflagellates Protoceratium reticulatum, Lingulodinium polyedrum and Gonyaulax spinifera. YTXs accumulate in shellfish and are toxic to mice by intraperitoneal injection [2, 3], producing symptoms similar to those of Paralytic Shellfish Poisoning (PSP) toxins. For these reasons YTXs had traditionally been included within the DSP group. However, more recently it has been proposed that YTXs should be excluded from the DSP group since they do not lead to diarrhea [3-5] and do not inhibit protein phosphatases [5]. On the other hand, YTXs have been found to be potent cytotoxins [68], prompting the European Authorities to establish a maximum permitted level in shellfish of $1 \mathrm{mg}$ YTX equivalents/Kg [9].

Together with YTX the existence of about 100 analogues have been reported to date from both bivalves or dinoflagellates, although only the structure of about forty of them have been identified and characterized by NMR and/or LC-MS/MS techniques $[10,11]$.

The toxin profile in different $P$. reticulatum strains have been found to be dependent on the origin of the strain [12-15]. Nevertheless, in spite of the high variability in the reported YTXs profile, it seems that the major toxin in P. reticulatum is usually YTX, and homoYTX was only found to be the main toxin in three Japanese strains [6, 16] and one Spanish strain [15].

This review covers the origin, chemical structures, metabolism, biosynthetic origin, toxicological properties, potential risks to human health and advances in detection methods of YTXs.

\section{Producer organisms and vectors of YTXs}

Yessotoxin (YTX) was first isolated in 1986 in Mutsu Bay, Japan [17] from the digestive gland of Patinopecten yessoensis, a scallop that gave its name to the toxin. Since then, it has also been found in the mussel Mytilus edulis (blue mussel) in Norway [18], Mytilus galloprovincialis from the Adriatic sea in Italy [19], Perna canaliculus (Greenshell mussel) from New Zealand, Mytilus chilensis from Chile [20], Mytilus galloprovinicalis from Galicia (Spain) [21], Mytilus edulis from Kandalaksha Gulf in the Russian White Sea [22] and Mytilus galloprovincialis from the Black Sea off the Russia Caucasian coast [23] (Figure 1). 
Figure 1. Presence of YTXs in molluscs in Japan, Norway, New Zealand, Italy, Chile, Spain and Russia (•). Identification of YTXs in Protoceratium reticulatum of: Japan, Italy, United Kingdom, Canada, Norway and Spain $(\boldsymbol{*})$.

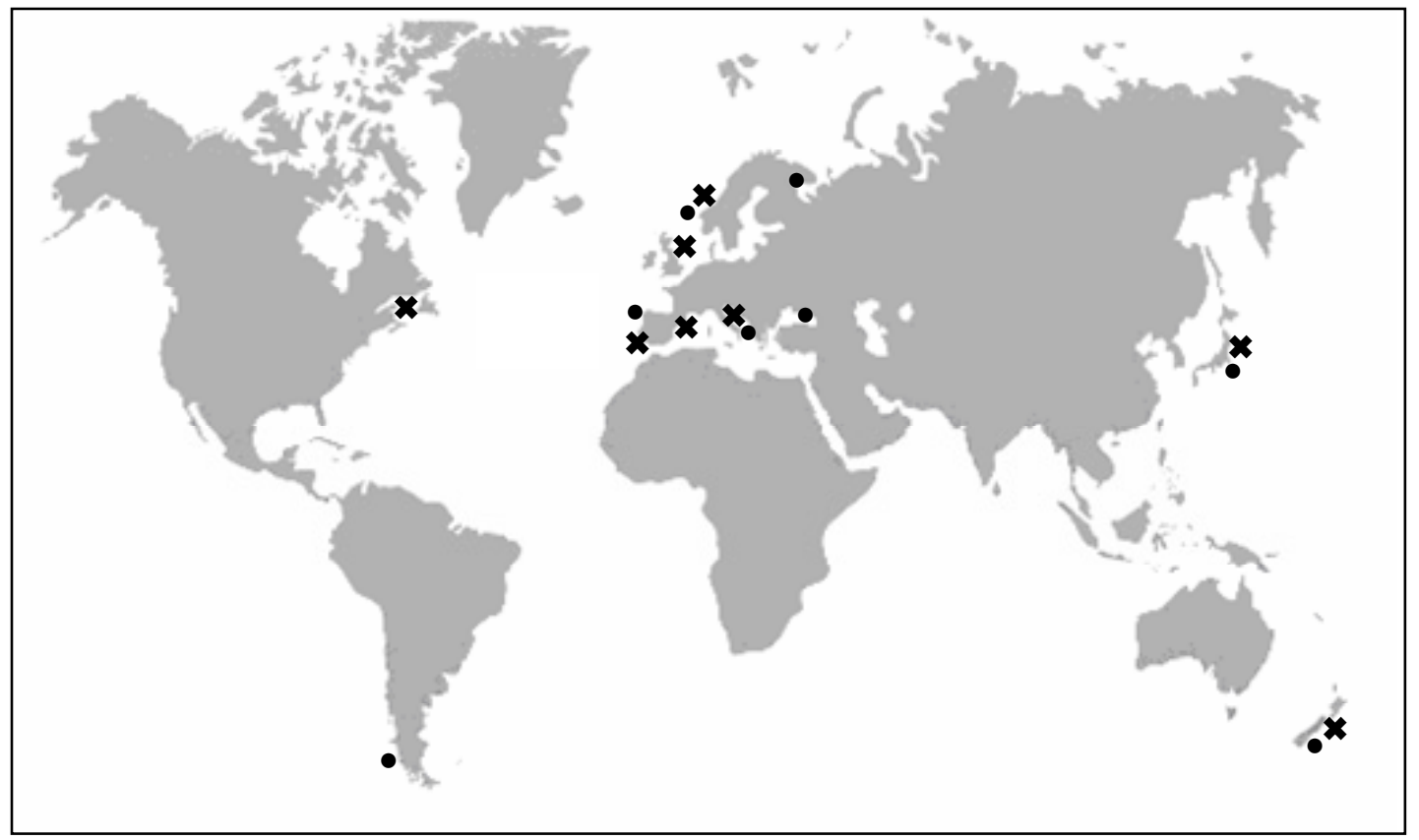

However, the dinoflagellate Protoceratium reticulatum (Claparède and Lachmann) Bütschli 1885, was the first unicellular organism identified as a producer of YTX. Subsequently, YTX has been found in cells of P. reticulatum from different places in Japan [12, 16, 24], in the Adriatic Sea in Italy [13], in Nova Scotia, Canada [25], in Norway [26] and in Spain [15, 27] (Figure 1).

The dinoflagellate Lingulodinium polyedrum (Stein) Dodge 1989 was also identified as a producer of YTXs, because L. polyedrum has been the main dinoflagellate detected in net-haul samples of several blooms in the Adriatic Sea containing YTX and homoYTX [4, 28], in Galicia in 2003 [21] and in mussels from the Russian Black Sea in 2007 [23]. YTXs have also been detected at low concentrations in cysts of different cultured strains of L. polyedrum in the United Kingdom [25]. However, although L. polyedrum seemed to be closely linked to the production of YTXs, this fact was not proved [29, 30] until YTX was found, in small quantities, in cultures of L. polyedrum from Galicia, Andalucía (Spain) [27] and California (USA) [31].

Other possible producers of YTXs have been reported: (i) It has been suggested that Coolia monotis [32] produce an analogue of YTX, the cooliatoxin, because it has the same molecular weight as 1desulfoYTX [33]. However, there is not enough information available about its chemical structure to confirm that it is indeed YTX. (ii) Gonyaulax spinifera has also been mentioned as a producer of YTX because two out of eight strains from New Zealand analysed by ELISA [34] showed very high concentrations of YTXs. However, previous LC/MS analysis of this organisms only gave a weak signal of YTX in one sample [25]. More recently G. spinifera was found, together with L. polyedrum, in plankton net samples during a mussel intoxication with YTX in Russia [23]. According to Hansen et al., (1996-97) [35], the morphology of G. spinifera is very similar to that of P. reticulatum so it could be a YTX producer. (iii) Some authors suggest that the real producers of YTXs are bacteria associated with the dinoflagellates, however to our knowledge, there is not solid evidence for this. 
As happens with other marine toxins, the principal vectors of YTXs are scallops and mussels, which can accumulate high quantities of YTXs due to their filtering feeding nature. It has been observed that even low concentrations of cells $\left(10^{3}\right.$ cells/L) are enough to produce the accumulation of important quantities of these toxins in shellfish [29]. Regarding the distribution of YTXs in mollusc tissues, they typically accumulate in the digestive gland, and in particular in the hepatopancreas, although they may also appear in the muscle tissue $[17,18,20,36]$. Within the digestive glands, YTXs are mainly present in the lumen of both tubules and ducts [37].

\subsection{Characteristics of YTX-producer dinoflagellates}

a) Protoceratium reticulatum (Claparède and Lachmann) Bütschli1885 (=Gonyaulax grindleyi Reinecke 1967)

It is thought that $G$. grindleyi is synonymous with $P$. reticulatum, however there is no consensus on its taxonomy. Besides, according to recent studies [15], $P$. reticulatum could be a group comprising several species, however deeper taxonomic studies are necessary to confirm this hypothesis. Very little biological knowledge of this species exists aside from the fact that it is a photosynthetic and thecate planktonic dinoflagellate belonging to the family Gonyaulacaceae. Its size oscillates between 28-43 $\mu \mathrm{m}$ in length and 25-35 $\mu \mathrm{m}$ in width [35]; it is shaped like a polyhedron with a strong theca made up of several plates; the theca has a prominent reticulation with pores in the center of each reticulation. It is bioluminescent [38] and forms spherical cysts with spines. Keeping in mind that it has been found in very different locations, it is reasonable to believe that $P$. reticulatum is able to grow within a wide range of temperature conditions, salinities, light, $\mathrm{pH}$ and nutrient conditions [39].

b) Lingulodinium polyedrum (Stein) Dodge 1989 (=Gonyaulax polyedra Stein 1883)

It is a thecate dinoflagellate belonging to the family Gonyaulacaceae. Cells are polyhedral-shaped and range in size from $40-54 \mu \mathrm{m}$ in length and $37-53 \mu \mathrm{m}$ in width. It is made up of thick plates, well defined, with a delicate reticulation and with numerous large trichocyst pores surrounded by circular sculpturing [40]. The girdle is deeply excavated, descending, and without intercrossings. It is bioluminescent [41]. Its life cycle involves vegetative reproduction, temporary cyst formation and sexual reproduction. The cysts are spherical (31-54 $\mu \mathrm{m}$ in diameter) with a double cell wall and a granular surface covered with spines. Living cysts present a prominent red body [42, 43]. It requires high levels of nutrients to develop; it is cosmopolitan and can be found mainly in temperate and subtropical coastal zones [40].

c) Gonyaulax spinifera (Claparède and Lachmann) Diesing 1866

It is also a thecate dinoflagellate with polyhedral form belonging to the family Gonyaulacaceae. Its size varies between 24-50 $\mu \mathrm{m}$ in length and 30-40 $\mu \mathrm{m}$ in width. It has a prominent and descending girdle, well excavated and with intercrossings. It also has two caudal spines [44, 45]. There are several different types of cysts associated with the moving cell of this species $[46,47]$ which is why it is believed that there could be more than one species under the name G. spinifera. It covers extensive geographical areas, from polar to tropical waters. 


\section{Structures of yessotoxin and its analogues}

The planar structure of YTX was determined using mass spectrometry (MS) and nuclear magnetic resonance spectroscopy (NMR) that revealed a molecular formula of $\mathrm{C}_{55} \mathrm{H}_{82} \mathrm{O}_{21} \mathrm{~S}_{2} \mathrm{Na}_{2}$ [17]. It is a disulfated polyether, with a characteristic ladder-shape formed by 11 adjacent ether rings of different sizes and a terminal acyclic unsaturated side chain consisting of 9 carbons and 2 sulfate ethers [17] (Figure 2).

The core structure is liposoluble, but two sulfate groups give an amphoteric molecule [20]. The presence of the sulfo-ether group makes these molecules the most polar ones of the lipophylic toxins group and, possibly due to this, important amounts of YTXs were found in the culture medium [15, 27, 48].

Figure 2. Structure of yessotoxin (YTX).

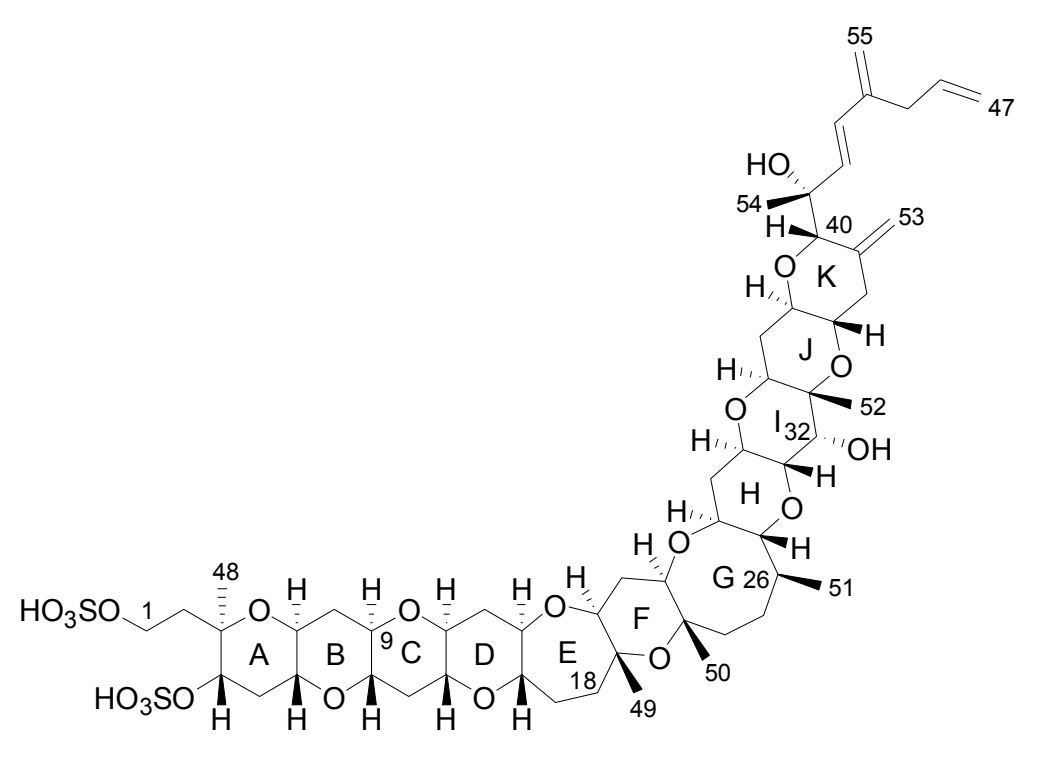

Numerous YTX congeners have been reported, and although the structure of some of them are still unknown [49], for many of them, full structure determination was carried out. Typically their molecular weight ranged between 955 and $1551 \mathrm{mu}$ [11, 49-51]. Currently 36 natural derivatives of YTX have been identified and characterized by NMR and/or liquid chromatography coupled with mass spectrometry (LC-MS). Some YTXs are directly produced by dinoflagellates while others are produced by the shellfish metabolism. Their structures are summarized in the following Figure 3. 
Figure 3. Structures of YTX analogues

$$
\text { (n) }
$$

Name

45-Hydroxy-YTX

(45OH-YTX)

45,46,47-Trinor-YTX

Homo-YTX

(1a-Homo-YTX)

45OH-Homo-YTX

Carboxy-YTX

Carboxyhomo-YTX

45OH-Carboxy-YTX
$\mathbf{R}$

$\left.\left.\underbrace{+}_{53}\right|_{55} ^{54}\right|_{45} ^{\mathrm{OH}} 47$

$\left.\right|_{41} ^{54} \mathrm{OH} \quad 45$

53

$\int_{41}^{54} \mathrm{OH}=45$

53

$\left.\left.\underbrace{H}_{53}\right|_{55} ^{54}\right|_{51} ^{47}>^{47}$

$\left.\left.\int_{41}^{54}\right|_{55} ^{\mathrm{OH}}\right|_{45} ^{\mathrm{OH}} 47$

2

$\left.\left.\right|_{41} ^{\mathrm{COOH}} \underset{\substack{\mathrm{COOH} \\ 53}}{\mathrm{O}}\right|_{45} ^{\mathrm{OH}}$

$\left.\left.\right|_{41} ^{\substack{\mathrm{COOH} \\ 53}} \underset{45}{44}\right|_{55} ^{\mathrm{OH}} 47$

$\underbrace{\left.\mathrm{H}\right|_{55} ^{\mathrm{COOH}}}_{53} \underbrace{54}_{\substack{45 \\ \mathrm{C}_{5}}} \mathrm{OH}$
1

2

[53]

2

[54]

[54]

1

[51]

2

Ref. 
Noroxo-YTX
$(41-$ Keto-YTX)
(Heptanor-41-oxo-YTX)
Noroxohomo-YTX
(41-Ketohomo-YTX)
(Heptanor-41-oxohomo-YTX)

40-epi-41-Keto-YTX

(40-epi-Heptanor-41-oxo-YTX)

41-Keto-YTX-1,3-enone

41a-Homo-YTX

41a-Homo-YTXamide

44,55-diOH-YTX

44,55-diOH-41a-Homo-YTX

45-OH-dinor-YTX

44-Oxotrinor-YTX

41a-Homo-44-oxotrinor-YTX
$\underbrace{+O_{42}^{O}}_{53}$

$\mathrm{H}_{42}^{\mathrm{O}}$

2

[58]

53

$\mathrm{H}_{=}^{\mathrm{O}}$

53

O

$\left.\right|_{41} ^{54}\left\|_{45}^{55}\right\|_{47}$

53

$\underbrace{\mathrm{O}}_{4141 \mathrm{a}} \|_{45}^{\mathrm{OH}} \mathrm{H}_{\mathrm{N}}^{\mathrm{O}}{ }_{\mathrm{OH}}^{\mathrm{OH}}$

$\int_{45}^{54} \mathrm{OH}{ }^{\mathrm{OH}}$

$53 \quad 55 \mathrm{OH}$

$\left.\underbrace{54}_{41 \mathrm{a}}\right|_{\mathrm{OH}} ^{45}{ }_{47}^{\mathrm{OH}}$

53

$\int_{53}^{54} \prod_{55}^{45} \mathrm{OH}$

1

$\left.\right|_{41} ^{54} \mathrm{OH}$

$53 \quad 55$

$\left.\right|_{41} ^{\mathrm{O}}{\underset{41 \mathrm{a}}{\mathrm{O}}}_{55}^{\mathrm{O}}$ 


$$
\text { Desulfoderivatives }
$$

Name

1-Desulfo-YTX

1-Desulfocarboxyhomo-YTX

4-Desulfocarboxyhomo-YTX

$\left.\left.\left.\right|_{53} ^{54}\right|_{55} ^{45}\right|_{51} ^{45}$

$\mathbf{R}$

47

$\left.\left.\underbrace{\mathrm{COOH}}_{53}\right|_{55} ^{54}\right|^{47}$

$\mathrm{R}_{1}=\mathrm{H} ; \mathrm{R}_{2}=\mathrm{SO}_{3} \mathrm{H}$

$\left.\left.\right|_{53} ^{\mathrm{COOH}}\right|_{55} ^{54}{ }^{\mathrm{COH}}$
Ref.

$\mathrm{R}_{1}=\mathrm{SO}_{3} \mathrm{H} ; \mathrm{R}_{2}=\mathrm{H}$

$$
\text { (1) }
$$


9-Methyl-41a-homo-YTX

44,55-diOH-9-Methyl-41a-homoYTX
$\int_{41}^{\mathrm{I}} \underbrace{54}_{41 \mathrm{a}} \|_{45}^{55} \mathrm{AH}_{47}$

1

[60]

53

$\left.\left.\right|_{41} ^{\mathrm{OH}}\right|_{45} ^{\mathrm{OH}} \underbrace{\mathrm{OH}}_{\mathrm{OH}}{ }_{1}^{\mathrm{OH}}$

[61]

$\left.\underbrace{54 a}_{41}\right|_{\mathrm{OH}} ^{45} \underbrace{\mathrm{OH}}_{47}$

1

[62]

$$
\text { Nor -ring-A }
$$

Name

$\mathrm{HIOH}$

Nor-ring-A-YTX

Nor-ring-A-41-keto-YTX

H

$\mathrm{H} \stackrel{\mathrm{O}}{\mathrm{H}}$

Nor-ring-A-40-epi-41-keto-YTX

Nor-ring-A-41-keto-YTX-1,3enone
Ref.

[60] 


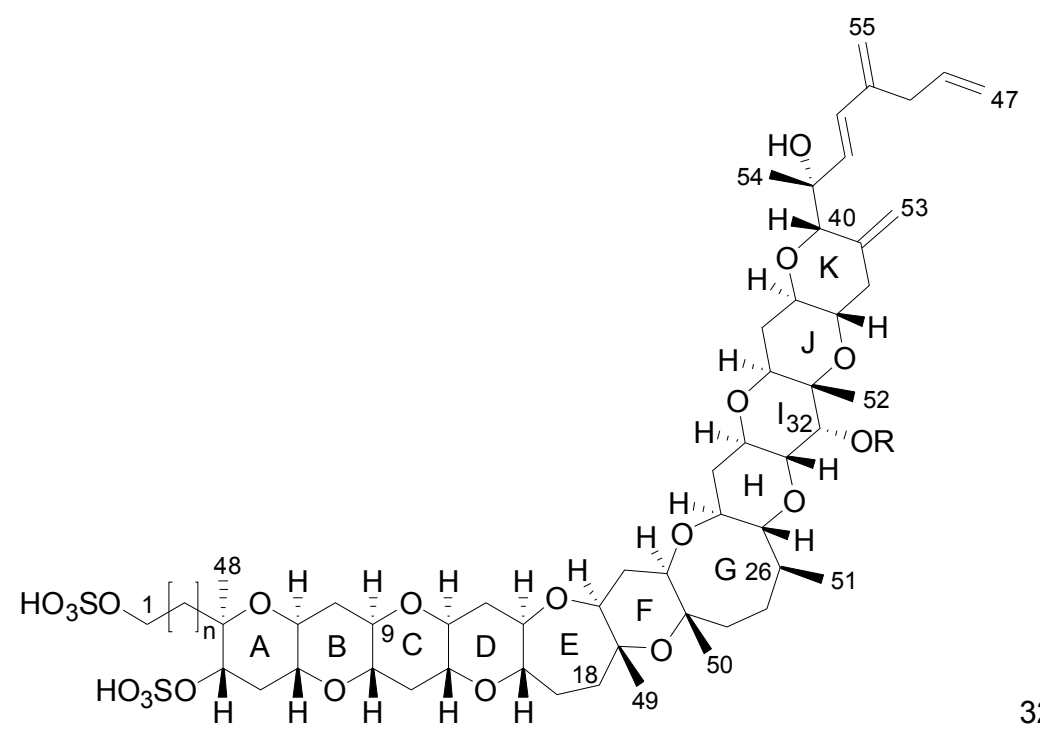

32-Glycosylderivatives

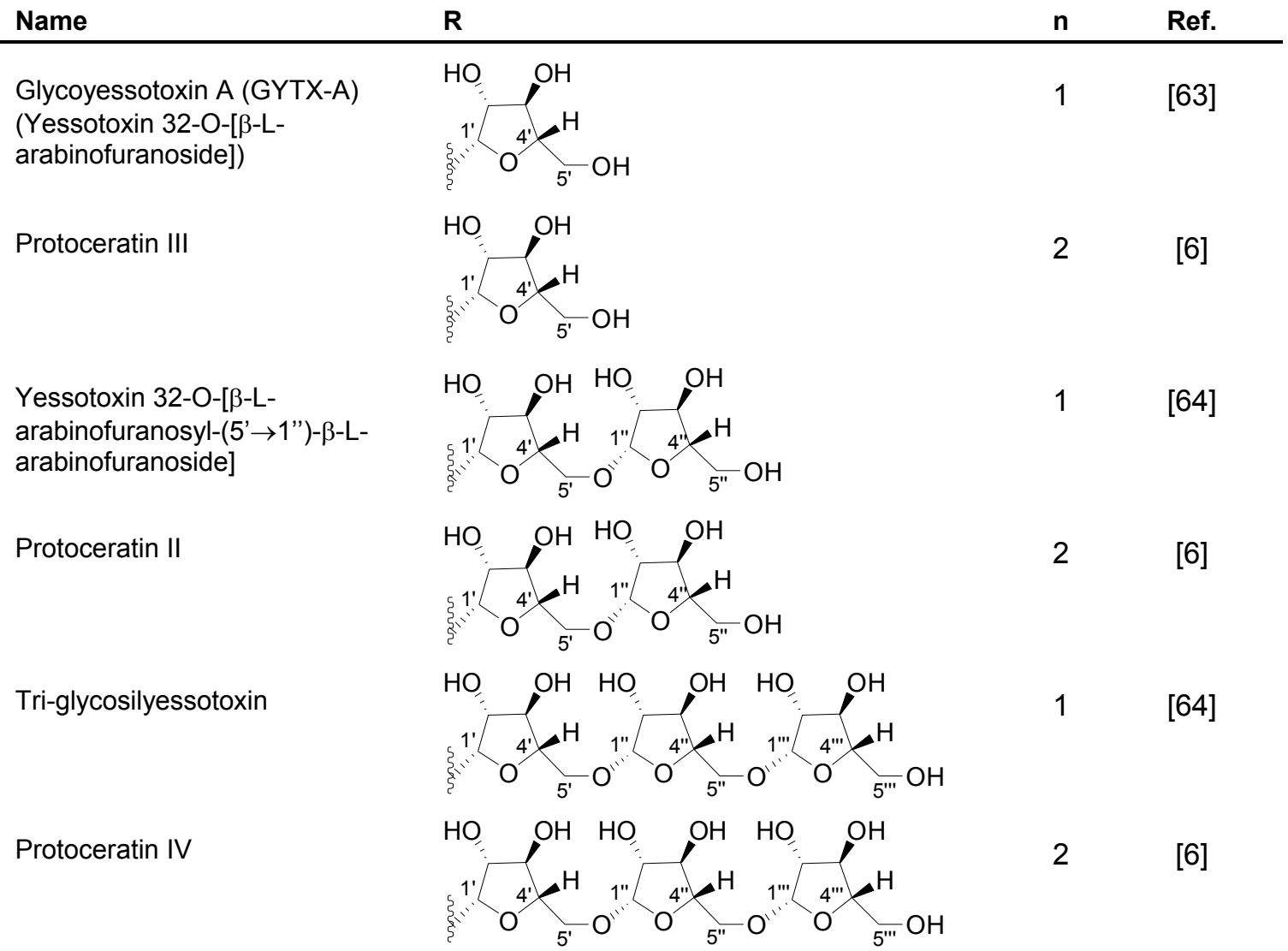

\subsection{Analogues detected in dinoflagellates}

P. reticulatum is the best studied YTX-producer as it is responsible for the majority of YTXs found in dinoflagellates. The first YTX analogue identified in algae was 45,46,47-trinor-YTX (=nor-YTX), isolated from a strain of $P$. reticulatum found in Yamada Bay in Japan [24]. Later, it was also found in Norway [26]. Other analogues recently isolated from this dinoflagellate are: homo-YTX (=1a-homoYTX) [13], noroxo-YTX [13, 49] (=42,43,44,45,46,47,55-heptanor-41-oxo-YTX or 41-keto-YTX), 40-epi-41-keto-YTX and 41-keto-YTXenone [59]; also 41a-homo-YTX, 9-methyl-41a-homo-YTX, four nor-ring-A-YTXs [60], 9-methyl-41-keto-YTXenone [11], 44,55-dihydroxy-YTX, 44,55- 
dihydroxy-41a-homo-YTX and 44,55-dihydroxy-9-Methyl-41a-homo-YTX [62], the hydroxyamideYTXs derived from 41a-homo-YTX and 9-methyl-41a-YTX [61]. In more recent studies 45-OHdinorYTX, 44-oxotrinor-YTX, 41a-homo-44-oxotrinor-YTX [11] and 45,46,47-trinorhomo-YTX [16, 53] (Figure 3) have been identified.

Compared to YTX, the previous derivatives showed differences due to hydroxilations, carboxylations, desulfatations, methylations, oxidations, amidations, changes in the length of the carbon chain or absence of the A ring [4, 11, 50, 59]. Recently the structure of a new class of derivatives was described resulting from glycosylation of the side chain of 1a-homo-YTX and YTX. These new derivatives possess 1, 2 or 3 arabinofuranose units linked to C-32 (Figure 3). The first glycoside derivatives discovered were 32-O-di-, -mono- and-tri-arabinofuranosyl-1a-homo-YTXs that were called respectively protoceratins II, III and IV [6]. Then 32-O-mono-arabinosyl-YTX [63] was identified, as well as 32-O-di and-tri-arabinofuranosyl-YTXs [64].

Another possible analogue isolated from Coolia monotis is the cooliatoxin [32], which coincidentally possesses the same molecular weight as 1-desulfo-YTX [33], however, there is no information about its chemical structure or toxic profile that could confirm its relationship to YTXs.

Table 1. Reported YTX concentration in different $P$. reticulatum strains.

\begin{tabular}{ccccc}
\hline $\begin{array}{c}\boldsymbol{P} \text { reticulatum } \\
\text { Strain }\end{array}$ & Location & $\begin{array}{c}\text { Analysis } \\
\text { Technique }\end{array}$ & $\begin{array}{c}\text { YTXs } \\
\text { (pg/cell) }\end{array}$ & Reference \\
\hline Yamada Bay & Japan & LC-FLD & $\mathbf{1 4}$ & {$[24]$} \\
New Zealand & New Zealand & LC-FLD & $\mathbf{3 . 0}$ & {$[24]$} \\
Mutsu Bay & Japan & LC-FLD & $\mathbf{0 . 9 - 1 1}$ & {$[12]$} \\
Emilia-Romagna & Italy & LC-FLD & $\mathbf{1 5 . 7}$ & {$[29]$} \\
VGO758 & Spain & LC-FLD & $\mathbf{2 8 . 7}$ & {$[15]$} \\
VGO764* & Spain & LC-FLD & $\mathbf{2 0 . 5} *$ & {$[15]$} \\
GG1AM & Spain & LC-FLD & $\mathbf{2 . 9}$ & {$[15]$} \\
UW351 & UK & LC-MS & $\mathbf{0 . 3}$ & {$[25]$} \\
UW409 & Canada & LC-MS & $\mathbf{5}$ & {$[25]$} \\
Adriatic & Italy & LC-MS & $\mathbf{1 1 . 4}$ & {$[13]$} \\
CAWD40 & New Zealand & LC-MS & $\mathbf{1 0 - 1 5}$ & {$[65]$} \\
OM6-NP31* & Japan & LC-MS & $\mathbf{7 1 . 7} *$ & {$[16]$} \\
10628-OK-PR-C & Japan & LC-MS & $\mathbf{5 9 . 8}$ & {$[16]$} \\
$020717-O K-P R-7$ & Japan & LC-MS & $\mathbf{1 . 0}$ & {$[16]$} \\
CAWD40 & New Zealand & ELISA & $\mathbf{3 0}$ & {$[26]$} \\
AP2 & Norway & ELISA & $\mathbf{1 9 - 2 2}$ & {$[26]$} \\
Sognfj03 & Norway & ELISA & $\mathbf{1 9 - 3 4}$ & {$[26]$} \\
CAWD40 & New Zealand & ELISA & $\mathbf{8 . 3}$ & {$[34]$} \\
\hline
\end{tabular}

* LC-MS analyses determined that the main toxin in VGO764 and OM6-NP31strains is homo-YTX.

In spite of the fact that $P$. reticulatum is able to produce numerous analogues of YTX, usually the most prominent toxin produced is YTX, with the exception of certain strains that produce homo-YTX as their principal toxin $[15,16]$. It has been shown that noroxoYTXs, trinor-YTXs [14] and glycosyl- 
YTXs [15] make up the most important percentage of all the analogues. The concentrations and profiles of toxins differ among distinct strains and can even be found in non-YTX-producing strains (Table 1). This is possibly due to genetic differences among $P$. reticulatum but can also be influenced by culture conditions and extraction methods for each toxin [15].

\subsection{Analogues detected in shellfish}

The first YTX analogue detected in molluscs was 45-hydroxy-YTX from P. yessoensis in Japan [52]. Afterwards, the analogue 45, 46, 47-trinor-YTX was identified from the same species [50]. Subsequently, other analogues were found in mussels (Mytilus galloprovincialis) from the Adriatic Sea, such as homo-YTX, 45-hydroxyhomo-YTX [54] (Figure 3), adriatoxin [66] (Figure 4), carboxyYTX [51], carboxyhomo-YTX [55], noroxohomo-YTX [58] (=42, 43, 44, 45, 46, 47, 55-heptanor-41oxohomo-YTX or 41-ketohomo-YTX) and noroxo-YTX [57] (=42,43,44,45,46,47,55-heptanor-41oxo-YTX or 41-keto-YTX) and 1-desulfo-YTX in Mytilus edulis from Norway [33]. More recently 41a-homo-YTX, 44,45-dihydroxy-YTX [62, 67] and 45-hydroxycarboxy-YTX [56] were discovered in Mytilus edulis from Norway. The most recent analogues identified in molluscs are two desulfoYTXs detected in mussels from the Adriatic Sea: 1-desulfocarboxyhomo-YTX and 4desulfocarboxyhomo-YTX [10] (Figure 3). In spite of the high number of analogues found in molluscs, the most abundant is typically 45-hydroxy-YTX, followed by carboxy-YTX.

Figure 4. Structure of adriatoxin.

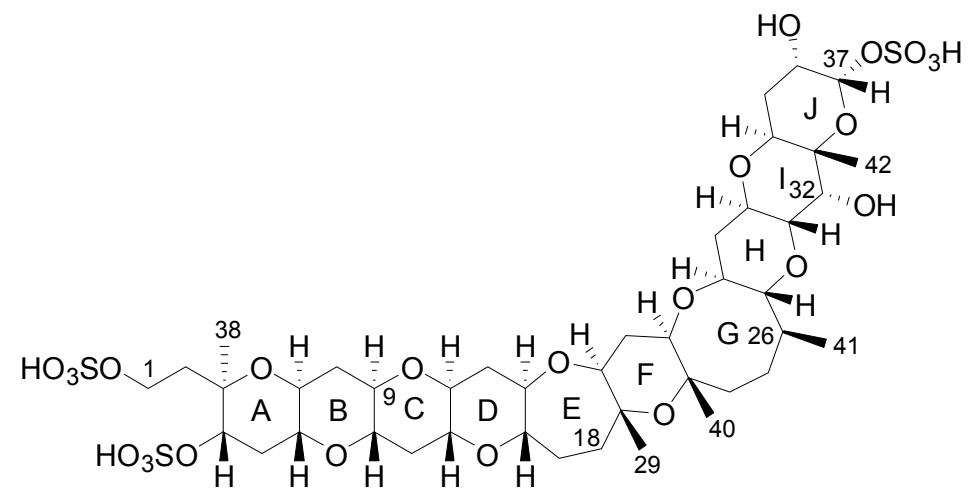

Initial results about the metabolism of YTX in molluscs indicated that both YTX and homoYTX are probably oxidized to 45-OH-YTX and 45-OHhomo-YTX respectively [20]. More recent studies indicate that the mollusc rapidly oxidizes YTX to 45-OH-YTX and more slowly to carboxyYTX. Afterwards, 45-OH-YTX is possibly metabolized to 45-OHcarboxy-YTX [56] (Figure 5). These hypotheses rely on the fact that the majority of YTXs found in molluscs are 45-OH-YTX and carboxyYTX $[36,68]$. 
Figure 5. Metabolism in bivalves.

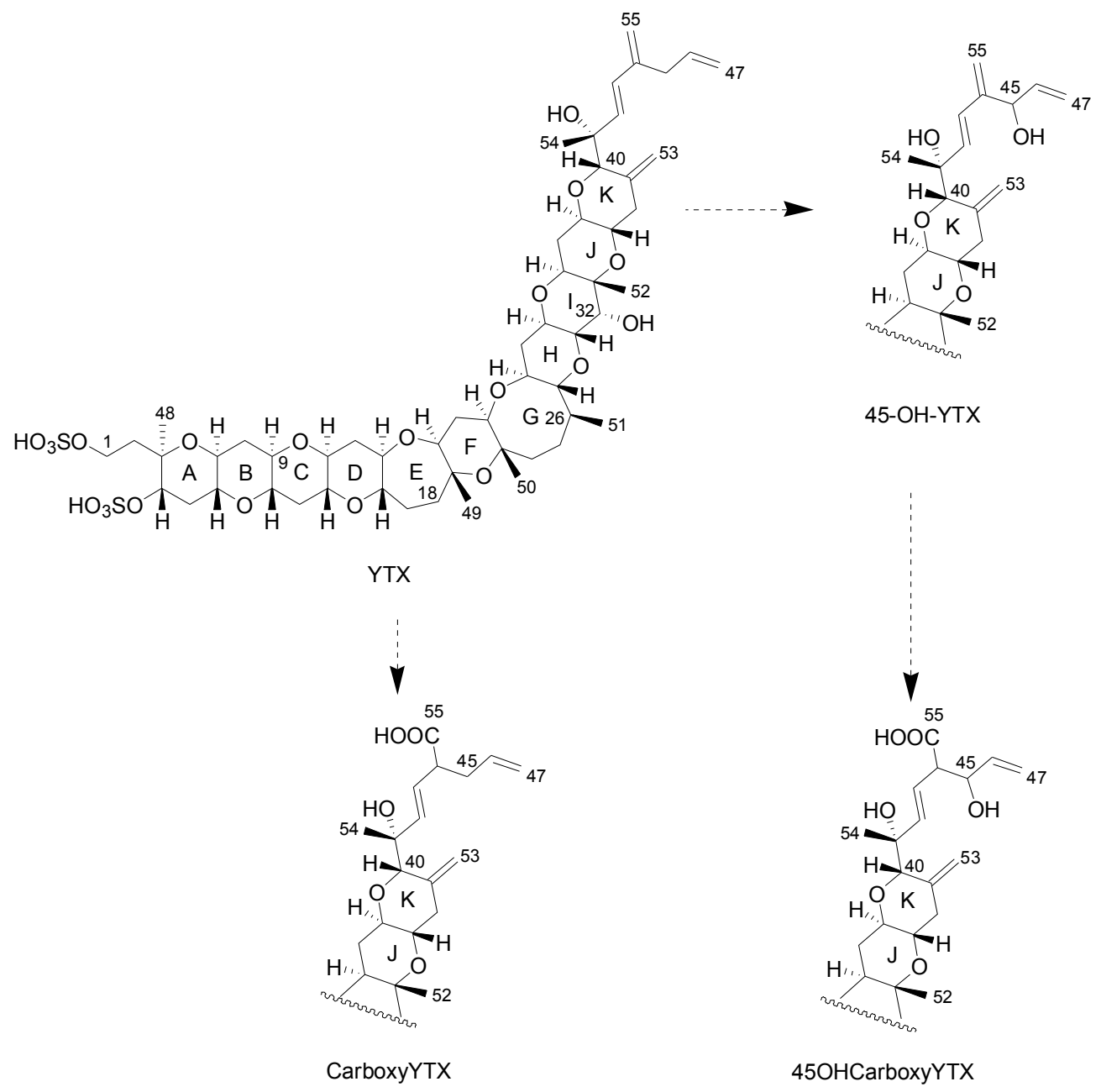

There is a controversy as to whether some of the analogues are produced exclusively by molluscs or by dinoflagellates. According to Ciminiello et al. [13], a small percentage of the 45-OH-YTX, 45OHhomo-YTX, carboxy-YTX and carboxyhomo-YTX are produced directly by the algae, but it is known that the major part of the 45-OH-YTX, carboxy-YTX and its homo form are produced by the metabolism of YTX and homo-YTX in molluscs [69]. In addition, in recent studies, neither 45-OHYTX nor carboxy-YTX were found in dinoflagellates [15, 26, 49].

\section{Biosynthetic origin of yessotoxin}

The only experimental data available on the byosynthetic origin of YTX come from a ${ }^{13} \mathrm{C}$ feeding experiment done by Satake in 2000 [70]. The dinoflagellate $P$. reticulatum was cultured in the presence of $\left[1-{ }^{13} \mathrm{C}\right],\left[2-{ }^{13} \mathrm{C}\right]$ and $\left[1-2-{ }^{13} \mathrm{C}\right.$ ] sodium acetate and [methyl- $\left.{ }^{13} \mathrm{C}\right]$ methionine. The experiments indicated that 15 carbons in YTX were labelled with $\left[1-{ }^{13} \mathrm{C}\right]$ acetate while 37 carbons were labelled with $\left[2-{ }^{13} \mathrm{C}\right]$ acetate (Figue 6). However, carbons C-1, C-2 and C-50 were not labelled with acetate. Similarly with the brevetoxins, the C-50 was labelled with [mehtyl- ${ }^{13} \mathrm{C}$ ] methionine. Unfortunately, these results were only published in a Japanese journal so we are not able to comment further on them. 
Figure 6. Results of labelling in yessotoxin ( $\mathrm{m}$ : methyl from acetate, c: carboxyl from acetate, c-m: acetate unit and M: methyl group from methionine).

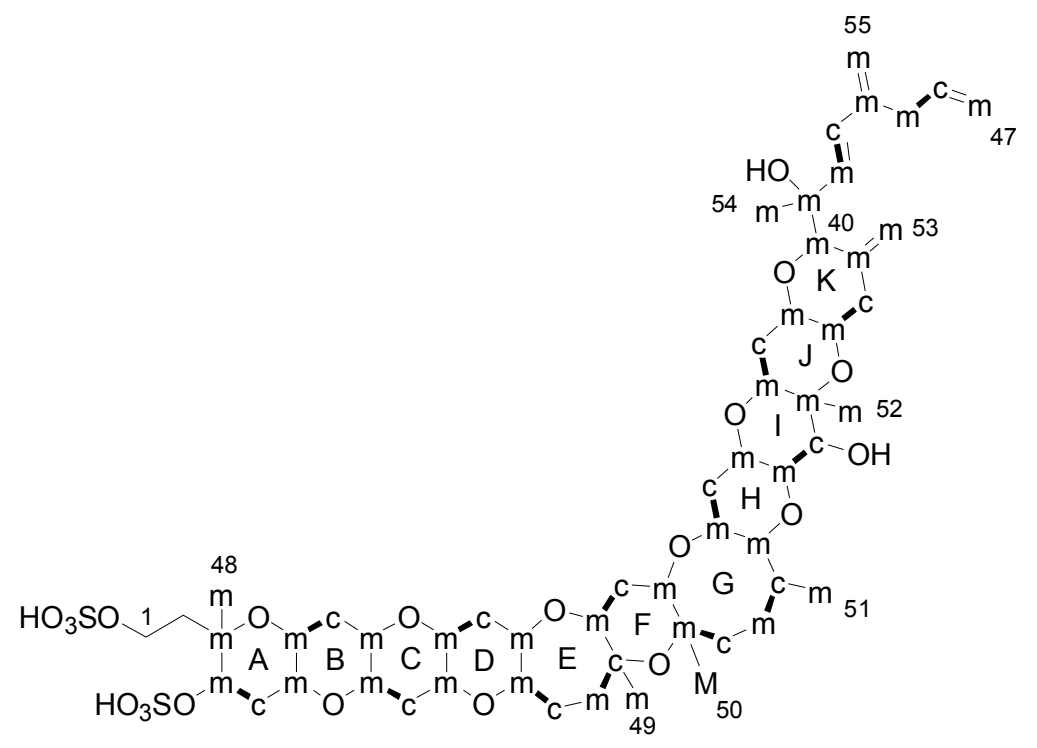

Furthermore, in 1985 Nakanishi, suggested that the dinoflagellates create this compound by launching a cascade of reactions that break apart a series of small rings as the first step to adding successive rings to the leader [71]. In the same line, an extraordinary work was published recently by Vilotijevic and Jamison, from a synthetic organic chemistry laboratory at the Massachusetts Institute of Technology (MIT) in Cambridge [72]. The authors report experimental evidence, in similar way to that proposed by Nakanishi, that using the appropriate polyepoxide system it is possible to obtain the A-D ring fragment of yessotoxin just using water. These results support the idea that marine dinoflagellates may build their toxins in a similar way (Figure 7).

\section{Toxicity and mode action of yessotoxins}

Symptoms of intoxication produced by YTX in humans are relatively unknown due to the fact that no human intoxication has been reported to date. However, it seems clear that YTX does not produce diarrhea in humans $[73,74]$. Despite about forty natural derivatives of YTX having been identified, the toxicological potential of YTXs is not yet completely clarified, and only YTX, desulfo-YTX, homoYTX and 45-OHhomo-YTX have undergone deep toxicological studies. Furthermore, the toxicological studies that discuss this issue are based on oral ingestion and intraperitoneal administration to mice and show great differences among them:

\subsection{Intraperitoneal toxicity}

The toxicity of YTX by intraperitoneal injection (i.p.) is high and a concentration of approximately $100 \mu \mathrm{g} / \mathrm{Kg}$ is lethal to all mice [5] (Table 2). The symptoms observed in mice injected with lethal doses of YTX and homo-YTX are similar to those found for PSP (Paralytic Shellfish Poisoning) toxins. The symptoms start within four hours of the injection and are characterized by signs of exhaustion, so the mice die quickly by sudden dyspnoea. Electron microscopy studies revealed that the 
toxin produces damage in the cardiac muscle $[3,73,75]$, as well as in the liver and pancreas $[2,5]$, and more recently it was reported that YTX also produces neuronal damage in the brain [76, 77]. Therefore, YTXs should be considered as potentially toxic for humans, with a lethal dose $\left(\mathrm{LD}_{50}\right)$ that varies among the different analogues between 80 and $750 \mu \mathrm{g} / \mathrm{Kg}$ (Table 2).

Figure 7. Synthesis of a similar fragment A-D of yessotoxin.

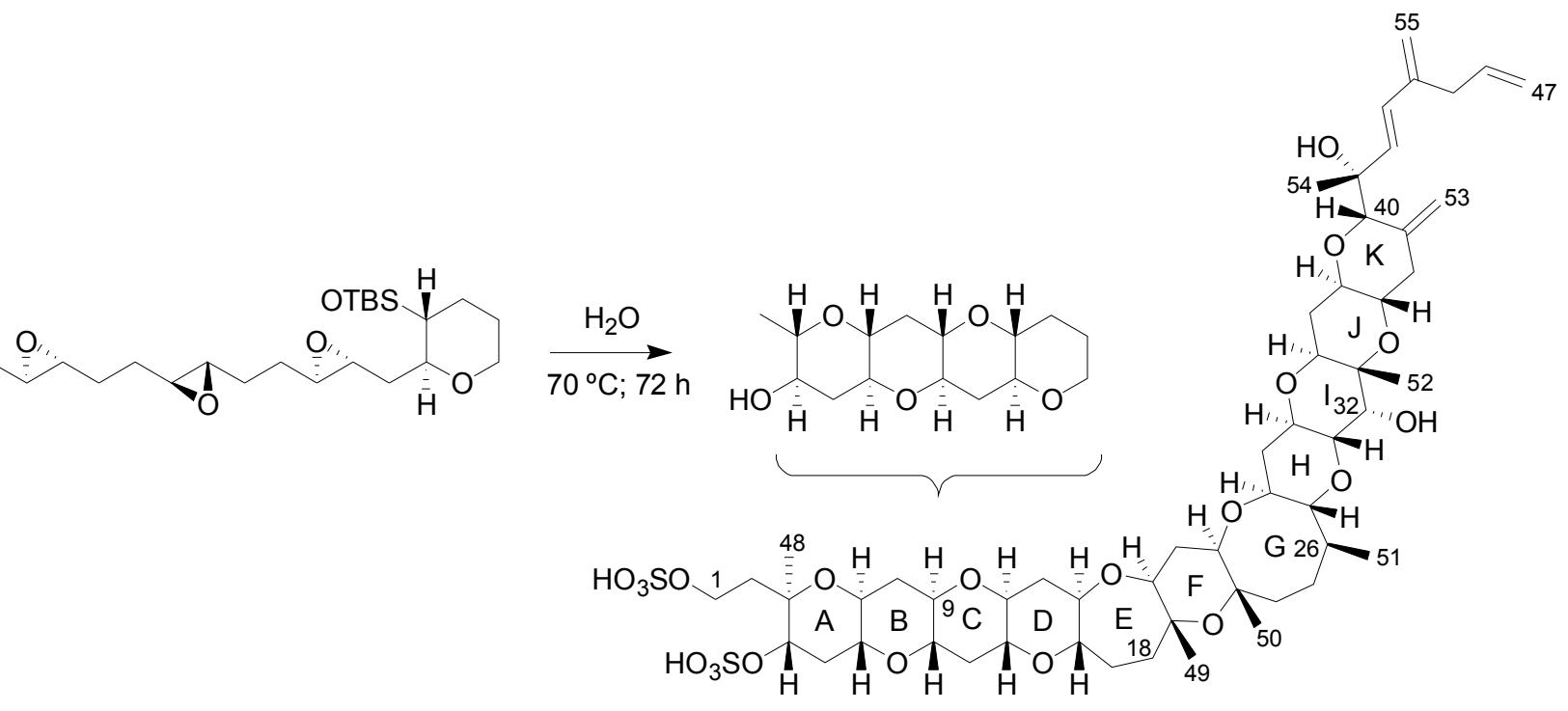

Table 2. Lethal Doses $\left(\mathrm{LD}_{50}\right)$ of YTXs.

\begin{tabular}{lll}
\hline Toxin & $\mathbf{L D}_{\mathbf{5 0}}(\boldsymbol{\mu} \mathbf{g} / \mathbf{k g})$ & Reference \\
\hline YTX & $80-750$ & {$[2,5,17,73]$} \\
Homo-YTX & 100 & {$[54]$} \\
Trinor-YTX & 220 & {$[50]$} \\
45OH-YTX & 500 & {$[50]$} \\
45OHhomo-YTX & 500 & {$[54]$} \\
1-Desulfo -YTX & 500 & {$[33]$} \\
Carboxy-YTX & 500 & {$[51]$} \\
Carboxyhomo-YTX & 500 & {$[55]$} \\
\hline
\end{tabular}

\subsection{Oral toxicity}

YTX is not lethal to mice after oral acute $10 \mathrm{mg} / \mathrm{Kg}$ administration in mice $[2,3,5,73]$. Neither diarrhea nor digestive organ damage have been observed [19, 54, 73] and only small and temporary behavioral alterations can be observed at high doses $[2,5]$. Histopathological studies reveal a slight affectation of myocardial cells $[2,73]$ and, it seems that YTX can also affect the thymus and immune system at lethal and sublethal doses [76, 78].

Very few studies have been carried out regarding YTX analogues. These show that 45-OH-YTX and 1-desulfo-YTX have lower toxicity than YTX [33], and that homo-YTX is slightly more toxic than YTX [3]. Carboxy-YTX was also toxic to mice by i.p. injection [51]. Recent oral and i.p. acute toxicity studies [3] and also short-term studies of daily administration to mice of YTX, homo-YTX or 
45-OH-YTX showed that none of the three toxins were lethal or induced signs of toxicity [79]. Moreover, none of the four YTXs, 41-keto-YTXenone [59], 9-methyl-41-keto-YTXenone [61], 1desulfocarboxyhomoYTX and 4-desulfocarboxyhomo-YTX [10] are lethal to mice even after a high i.p administration.

Recent studies of oral toxicity in mice indicate that risk of intoxication by YTXs may be much less important than those from OA or dinophysistoxins, so it does not seem to be a serious problem for human health $[3,75,79]$. However, the extent by which these toxins can be absorbed by the intestine to reach their target organs still needs to be determined.

\subsection{Mode of action of yessotoxins}

The discrepancy between the oral and i.p. toxicity has prompted the interest of researchers to study the mechanism action of YTX. Although a good number of cytotoxic studies have been carried out and, a clearer pattern of the mode of action of YTX has emerged recently, the precise mechanism of action is not yet known. However, it seems clear that YTXs do not inhibit protein phosphatases PP1 and PP2A [5], as opposed to other lipophilic toxins, such as OA [5].

According to in vitro studies, it seems that YTX modulates the calcium homeostasis in human lymphocytes: on the one hand it induces an extracellular $\mathrm{Ca}^{2+}$ entry through $\mathrm{Ca}^{2+}$ channels sensitive to nifedipine and to SKF 96365, by modulating adenosine 3',5'-cyclic monophosphate (cAMP), and on the other hand YTX inhibits the capacitative entry of $\mathrm{Ca}^{2+}[80,81]$. It was also reported that YTX acts by activating phosphodiesterase (PDE) activity, therefore decreasing the level intracellular of cAMP, depending on the presence of $\mathrm{Ca}^{2+}$ in the extracellular medium of human lymphocytes [82-84]. Subsequent studies have indicated that YTX produces apoptosis in different types of cells such as human neuroblastoma [85], human HeLa cells [86] or rodent myoblast [75] by induction of different caspase isoforms [75, 85-87]. Apoptotic events induced by YTX were associated with cytoskeletal disruption observed in rodent cells, such as cultured cerebelar neurons [8] and myoblast cell lines via mitochondrial pathway [87]. Recently, it has been demonstrated that the cytoskeleton disruption in mouse myoblast is caused by tensin cleavage [88].

Other recent in vitro studies demonstrated that YTX induces a selective disruption of the Ecadherin-catenin system in epithelial cells, such as MCF-7 breast cancer cells [89], or that YTX (in the presence of $\mathrm{Ca}^{2+}$ ) increases the mitochondrial membrane permeability of rat liver mitochondria [7]. Additional studies showed that YTX affects the basic immune function [90] producing a cytoplasmatic $\mathrm{Ca}^{2+}$ increase in mussel immunocytes [90,91]. The lysosomal vesicles and cytoskeletal microfilaments were identified as the cell components mainly involved in the early apoptotic response to YTX in both insect and mouse fibroblast cells [92].

Finally, a structure-activity relationship (SAR) has been proposed for YTXs. Differences in activity among YTX analogues were detected when structural changes affected the C-9 terminal chain of YTX, showing that this portion of the molecule is essential for the activity of YTX in MCF-7 breast cancer cells [93]. 


\section{Detection and quantification methods for yessotoxin and its analogues}

The determination of YTXs is complex due to the high number of existing analogues; because they have common solubility properties with other lipophilic toxins; and because they coexist in the phytoplankton and in the vectors. Various methods have been developed for the determination of YTXs and, apart from economical considerations, the choice mainly depends on the objectives of the study. In vivo assays are usually applied for public health protection, as the priority is to determine the potential global toxicity. Analytical methods are mostly applied in research or confirmatory studies when the identification and quantification of individual toxins are required.

\subsection{In vivo assays}

Mouse bioassay [94, 95] (MBA) is the official method accepted to detect YTXs [96]. This method involves acetone extraction, which can be partitioned with ethyl acetate/water or dichloromethane/water [96]. The solvent is removed and the residue is resuspended in $0.1 \%$ Tween $60.1 \mathrm{~mL}$ of this solution is injected i.p. into three mice with a body weight of about $20 \mathrm{~g}$. Mice are observed for 24 hours and the toxicity is determined on the basis of survival time and by the symptomatology. The toxicity is provided in mouse units (MU). $1 \mathrm{MU}$ is defined as the minimum amount of toxin required to kill 2 out of 3 mice within 24 hours.

The EU regulatory limit established for YTXs [9] in food is high (1 mg YTX equivalents/Kg) because it is based on the low oral toxicity to mice. Therefore using doses of YTX for MBA below this regulatory limit cause mice to die. In addition, this method is the same as that used to detect the lipophilic toxins okadaic acid (OA), dinophysistoxins (DTXs), pectenotoxins (PTXs) and azaspiracids (AZAs) which can be co-extracted due to their common solubility properties. Therefore with this method it is difficult to identify which toxin causes the death of the mice and it may give false positives [97]. Specific analytical methods for YTXs, such as LC-FLD or LC-MS [98, 99] are therefore required to be able to determine which toxin causes the positive result and to avoid this problem.

In general, the mouse bioassay is considered an inconvenient detection method for marine biotoxins because of its lack of specificity. Moreover, it is time consuming and expensive, free fatty acids might interfere with the results, the recovery of the YTXs from the extract is variable due to matrix effects and it is ethically questionable [100]. However, after many years of routine application, it has proved to be very effective to screen for the presence of DSP and other lipophilic toxins for public health protection purposes.

\subsection{In vitro assays}

a) Functional assays. These assays depend on a characteristic response linked to the mode of action of the toxin in cultured cells; therefore they correlate well with real toxicity. The disadvantages are that: viable cell-strains are necessary, they are sensitive to interferences and that expertise is required to perform the assays. In addition, it is not possible to distinguish between different YTX analogues using them. A series of functional assays for YTXs have been recently developed: 
- Cytotoxicity assays: Initially designed to detect DSP toxins, these assays are also able to detect YTXs [101]. These assays are based on the microscopic examination of the morphological changes observed in freshly prepared rat hepatocytes after toxin exposure. With these assays it is possible to differentiate between OA, DTX1, PTX1 and YTXs as OA and DTX1 induce irregularshaped cells with surface blebs, while PTX1 produces dose dependent vacuolisation or YTXs produce tiny blebs on the surface of cells but do not induce changes in the shape of the cells. However, this information is only qualitative, as cell changes produced by the toxins are not dose dependent.

- Accumulation of fragmented E-cadherin [102]: In this assay the accumulation of a $100 \mathrm{kDa}$ fragment of E-cadherin induced by YTX in the epithelial MCF-7 breast cancer cells is measured. The increase of the fragmentation of this fragment of E-cadherin is concentration-dependent and is detected by Immunoblotting using anti-E-cadherin antibodies. It is a very sensitive and specific method (detection limit around $100 \mu \mathrm{g}$ YTX equivalents/Kg) [103].

- Intracellular decrease of adenosine 3',5'-cyclic monophosphate (cAMP) [82, 104]: YTX in the presence of calcium activate PDEs activity with the consequent decrease in cAMP levels. This phenomenon is concentration-dependent and it is detected using a fluorescent derivative of cAMP, anthranyloyl-cAMP. To be exact, it is detected by a decrease in fluorescence, due to the improved hydrolytic effect of PDEs in anthranyloyl-cAMP [104]. The rate of cAMP hydrolysis is linearly correlated with different concentrations of YTX between 0.5 and $10 \mu \mathrm{M}$.

b) Structural assays (immunoassays) based on measurements of the recognition of this toxin by specific antibodies. However, these assays not necessarily related to the biological activity of the toxin, therefore any correlation with real toxicity is not always as good as it is for functional assays.

- ELISA (enzyme-linked immunosorbent assay): a specific ELISA to detect YTXs in shellfish, microalgae and/or seawater samples has been recently developed by Briggs et al. [105], and is now commercially available as a kit for rapid screening of YTXs [106]. It is a competitive, indirect immunoassay based on the use of polyclonal antibodies against YTX. The antibodies used, were obtained using conjugated YTX-protein (cBSA), and have a broad specificity for YTXs, because the YTXs have been conjugated in the non-sulphated end of the molecule. The working range is $70-1300 \mathrm{pgYTX} / \mathrm{mL}$. The disadvantages of this method are due to the crossreactivity of the antibody, and therefore it is not possible to distinguish among analogues. Moreover, the cross-reactivity of the antibodies is limited to compounds with specific compatible moieties, therefore it is not possible to detect all the analogues with the significant risk of obtaining false negatives. This assay has the advantage of being sensitive, rapid, relatively cheap, suitable for HTS screening large number of samples; it is affordable for most labs and operators require minimal training.

\subsection{Chemical methods}

Chemical methods consist of a first step of toxin separation followed by identification and quantification of each toxin. These methods rely on the measurement of an instrumental response that is proportional to the concentration of toxin. However, quantification always requires a previous 
calibration step of the equipment with toxin standards. The chemical methods used to determine YTXs are essentially liquid chromatography with fluorescence detection (HPLC-FLD) or coupled with mass spectrometry (LC-MS):

a) Liquid chromatography with fluorescence detection (HPLC-FLD) [20]: This method is extensively used for the qualitative and quantitative analysis of YTXs both in molluscs and microalgae [107]. It is based on the determination of a fluorescent derivative of the toxin obtained by precolum derivatization with the dienophile reagent 4-(2-(6,7-dimethoxy-4-methyl-3-oxo-3,4dihydroquinoxalimylethyl)-1,2,4triazoline-3,5-dione (DMEQ-TAD) (Figure 8).

Figure 8. DMEQ-TAD derivatization reaction for yessotoxin

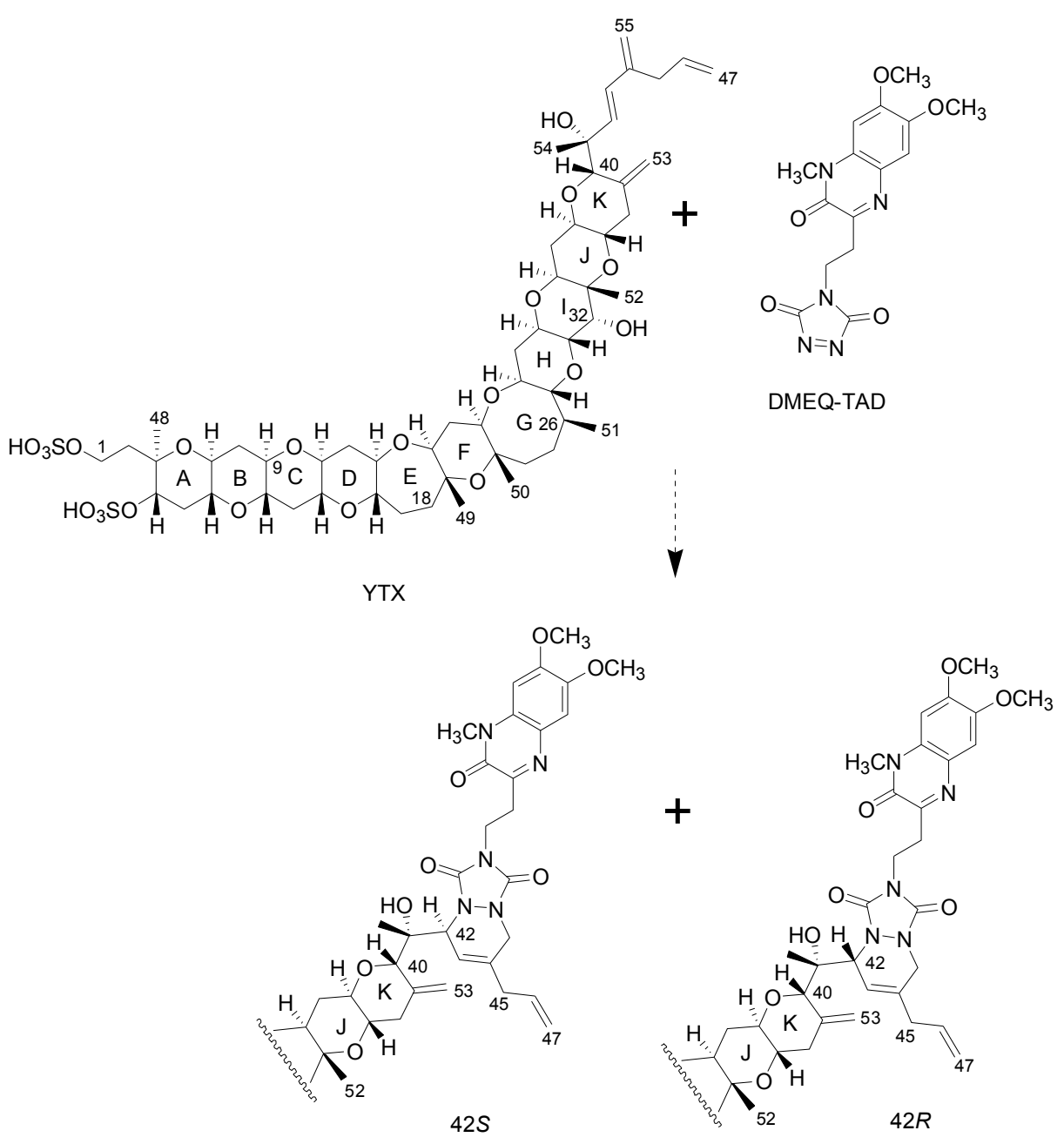

Previous to the analysis, a clean-up of the sample using solid phase extraction (SPE) cartridges is required to eliminate interferences. The fluorogenic reagent reacts with the conjugated diene in the side-chain and, as a consequence, this method can only detect YTX, 45-OH-YTX, trinor-YTX [20], desulfo-YTX [33], homo-YTX, 45-OHhomo-YTX and G-YTXs [108]. Other analogues such as carboxy-YTX, diOH-YTX, and noroxo-YTX or adriatoxin without the diene moiety can not be detected by HPLC-FLD. The fluorescent adduct gives two diasteroisomeric peaks due to the formation of both C-42 epimers in a 3:1 ratio for YTX (Figure 8) [20]. YTX analogues elute at different retention times, therefore the use of toxin standards is necessary for toxin identification. 
Weaknesses of this method are that the detection of new analogues are limited to the presence of a conjugated diene, and that it is difficult to distinguish between analogues with similar retention times, such as YTX and homo-YTX [15]. On the other hand, advantages are that it is a very sensitive method with a linear response $(0.4-6 \mathrm{mg} / \mathrm{Kg})$, requires relatively low-cost equipment, it is affordable to many labs and it is faster than the mouse bioassay.

b) Liquid chromatography coupled with mass spectrometry (LC-MS): currently this is the most powerful analytical tool used to identify multiple toxins. This technique has several advantages, such as its high sensitivity and selectivity. In addition, collision experiments (MS/MS) can provide valuable structural information in the confirmation of toxin identities, as well as in the identification of new toxins. It does not require complex derivatization and purification steps needed for HPLC-FLD methods. It is possible to analyze all the YTXs, even those derivatized with DMEQ-TAD [108], and also different algal toxins. In fact, several multi-toxin detection methods have been developed [109]. However, as is the case for other chemical methods, calibration standards are required for method development and toxin quantification. LC-MS methods can provide relevant information about the presence of compounds related to a known structure, even if the toxin standard is available only for one relevant toxin of the group. The main disadvantage of this technique is that the equipment is expensive.

Several specific LC-MS methods have been developed for YTX detection, which differ basically in the mobile or stationary phase used or the electrospray mode selected (positive or negative) [25, 110115]. Most methods use negative ion mode detection because YTXs easily lose a proton from the sulfate group. The fragmentation of YTX is achieved easily even when low collision energies (C.E.) are used and the loss of the sulfate group and the subsequent fragmentation of the unsaturated side chain are characteristic (Figure 9) [111]. Recently an ultra-performance liquid chromatography mass spectrometry (UPLC) method has been developed [116].

c) Capillary electrophoresis with UV/MS detection: This is an analytical method designed as an alternative to HPLC-FLD for the determination of YTXs. It shows high resolution and small amounts of sample are required. Coupled with MS instrumentation it allows confirmation of the presence of YTXs in samples [117].

\section{Current regulations for yessotoxins}

Taking into account the existing knowledge about YTXs, in 2002 these toxins were classified and regulated separately from the DSP toxins by the European Commission with the Directive 2002/225/EC [118]. This Directive was recently derogated by Regulation No 853/2004/EC [9], which was amended by Regulation 2074/2005/EC [96] of the European Commission.

Regulation $\mathrm{N}^{\circ} 853 / 2004 / \mathrm{EC}$ establishes the maximum permitted levels of some marine biotoxins in molluscs for human consumption. In the case of YTXs the regulatory limit is $1 \mathrm{mg}$ of YTX equivalents/Kg (measured in the whole body or any edible part separately) (Chapter V, Section VII of Annex III of the Regulation). Regulation 2074/2005/EC lays down the recognised testing methods for detecting marine biotoxins by the competent authorities (Annex III of the Regulation). According to this Regulation a single mouse bioassay may be used to detect OA, DTXs, PTXs, YTXs and AZAs. Due to the lack of specificity of the mouse bioassay, it is not possible to distinguish which of the 
lipophilic toxins contribute to the toxic effects that may be observed, and both false negatives or positives are known to occur. Therefore it is clear that a solution to this analytical problem is still an open-ended question. In this sense Regulation 2074/2005/EC also states that methods, such as HPLCFLD, LC-MS, inmunoassays and functional assays, may be used as alternatives or supplementary to the biological methods, if they are not less effective than the biological methods and if their implementation provides an equivalent level of public health protection (Annex III of the Regulation).

Figure 9. Characteristic product ions in $\mathrm{MS}^{3}$ fragmentation of $[\mathrm{M}-\mathrm{H}]^{-}$ions of common yessotoxin skeletons $(n=1)$ and above of homoyessotoxin skeletons $(n=2)$.

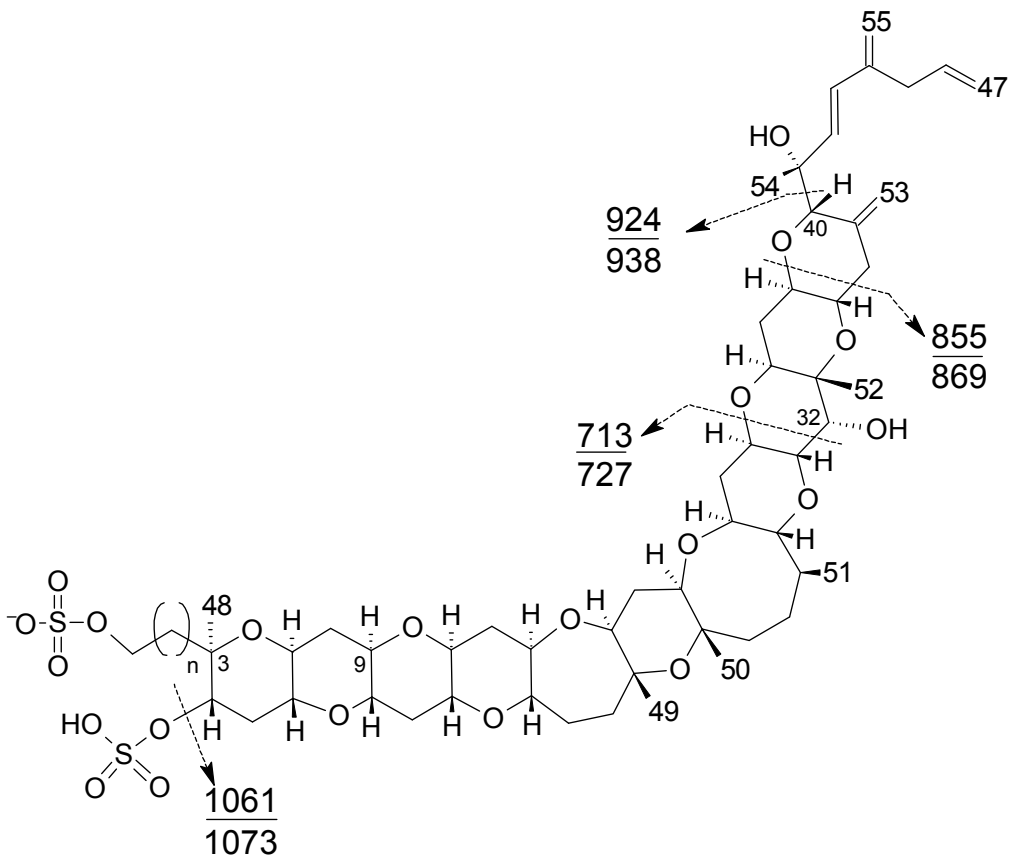

Finally, the Directive also states that if new analogues of importance to public health are discovered they should be considered, and that biological methods shall be replaced by alternative detection methods as soon as reference materials for detecting the toxins prescribed in Chapter $\mathrm{V}$ of Section VI of Annex III to Regulation (EC) No 853/2004 are readily available and the methods have been validated.

\section{Conclusions}

As stated in this review, different aspects of the toxicology of YTXs are relatively unknown, and this fact, together with the high structural variability in the YTX analogues mean that YTXs require further study. The scarcity of toxicological studies on YTX and its analogues, which are necessary to assess its human health risks, have been hampered until now, by the limited availability of the toxin. Reference YTXs are needed, but the availability of such standards is very limited or they are not commercially available at all. For all these reasons, the study of YTX and its analogues is still an important challenge for all those groups dedicated to the study of marine natural products. 


\section{Acknowledgements}

We thank Santiago Fraga and Isabel Bravo for their useful discussions. Authors acknowledge financial support from the Spanish MEC (AGL2005-07924-C04-01 and 02/ALI), INIA (ACU-02-005) and CCVIEO projects

\section{References and Notes}

1. Moestrup, Ø.; Codd, G. A.; Elbrächter, M.; Faust, M. A.; Fraga, S.; Fukuyo, Y.; Cronberg, G.; Halim, Y.; Taylor, F. J. R.; Zingone, A. IOC Taxonomic Reference List of Toxic Algae, UNESCO. http://ioc.unesco.org/hab/data.htm. 2004.

2. Aune, T.; Sorby, R.; Yasumoto, T.; Ramstad, H.; Landsverk, T. Comparison of oral and intraperitoneal toxicity of yessotoxin towards mice. Toxicon 2002, 40, 77-82.

3. Tubaro, A.; Sosa, S.; Carbonatto, M.; Altinier, G.; Vita, F.; Melato, M.; Satake, M.; Yasumoto, T. Oral and intraperitoneal acute toxicity studies of yessotoxin and homoyessotoxins in mice. Toxicon 2003, 41, 783-792.

4. Tubaro, A.; Sidari, L.; Della-Loggia, R.; Yasumoto, T. Occurrence of yessotoxin-like toxins in phytoplankton and mussels from northern Adriatic Sea. In: Reguera, B.; Blanco, J.; Fenández, M. L.; Wyatt, T., eds. Harmful Algae: Xunta de Galicia and IOC of UNESCO, 1998, 470-472.

5. Ogino, H.; Kumagai, M.; Yasumoto, T. Toxicologic evaluation of yessotoxin. Nat. Toxins 1997, 5, 255-259.

6. Konishi, M.; Yang, X.; Li, B.; Fairchild, C. R.; Shimizu, Y. Highly cytotoxic metabolites from the culture supernatant of the temperate dinoflagellate Protoceratium cf. reticulatum. J. Nat. Prod. 2004, 67, 1309-1313.

7. Bianchi, C.; Fato, R.; Angelin, A.; Trombetti, F.; Ventrella, V.; Borgatti, A. R.; Fattorusso, E.; Ciminiello, P.; Bernardi, P.; Lenaz, G.; Parenti, C. G. Yessotoxin, a shellfish biotoxin, is a potent inducer of the permeability transition in isolated mitochondria and intact cells. Biochim. Biophys. Acta 2004, 1656, 139-147.

8. Pérez-Gómez, A.; Novelli, A.; Ferrero-Gutiérrez, A.; Franco, J. M.; Paz, B.; FernándezSánchez, M. T. Potent neurotoxic action of the shellfish biotoxin yessotoxin on cultured cerebellar neurons. Toxicol. Sci. 2006, 90, 168-177.

9. EC. Regulation No 853/2004 of the European Parlamient and of the Council of 29 April 2004, laying down specific hygiene rules for food of animal origin. 2004, L 226, p. 22.

10. Ciminiello, P.; Dell-Aversano, C.; Fattorusso, E.; Forino, M.; Grauso, L.; Magno, S.; Poletti, R.; Tartaglione, L. Desulfoyessotoxins from Adriatic Mussels: a new problem for seafood safety control. Chem. Res. Toxicol. 2007, 20, 95-98.

11. Miles, C. O.; Wilkins, A. L.; Allan, D. H.; Selwood, A. I.; Jensen, D. J.; Cooney, J. M.; Beuzenberg, V.; MacKenzie, A. L. Identification of 45-hydroxy-46,47-dinoryessotoxin, 44oxo-45,46,47-trinoryessotoxin, and 9-methyl-42,43,44,45,46,47,55-heptanor-38-en-41oxoyessotoxin, and partial characterization of some minor yessotoxins, from Protoceratium reticulatum. Toxicon 2006, 47, 229-240. 
12. Eiki, K.; Satake, M.; Koike, K.; Ogata, T.; Mitsuya, T.; Oshima, Y. Confirmation of yessotoxin production by the dinoflagellate Protoceratium reticulatum in Mutsu Bay. Fish Sci. 2005, 71, 633-638.

13. Ciminiello, P.; Dell-Aversano, C.; Fattorusso, E.; Forino, M.; Magno, S.; Guerrini, F.; Pistocchi, R.; Boni, L. Complex yessotoxins profile in Protoceratium reticulatum from northwestern Adriatic sea revealed by LC-MS analysis. Toxicon 2003, 42, 7-14.

14. Samdal, I. A.; Olseng, C. D.; Sandvik, M.; Miles, C. O.; Briggs, L.; Torgersen, T.; Jensen, D. J.; Cooney, J. M. Profile of yessotoxin analogues in a Norwegian strain of Protoceratium reticulatum. In: Henshilwood, K., Deegan, B., McMahon, T., Cusack, C., Keaveney, S., Silke, J., O'Cinneide, M., Lyons, D., Hess, P., ed. Galway, Ireland, 2006, 118.

15. Paz, B.; Riobó, P.; Ramilo, I.; Franco, J. M. Yessotoxins profile in strains of Protoceratium reticulatum from Spain and USA. Toxicon 2007, 50, 1-17.

16. Suzuki, T.; Satake, M.; Yoshimatsu, S.; Oshima, Y.; Horie, Y.; Koike, K.; Iwataki, M. Yessotoxin analogues in several strains of Protoceratium reticulatum in Japan determined by liquid chromatography-hybrid triple quadrupole/linear ion trap mass spectrometry. $J$. Chromatogr. A 2007, 1142, 172-177.

17. Murata, M.; Masanori, K.; Lee, J.-S.; Yasumoto, T. Isolation and structure of Yessotoxin, a novel polyether compound implicated in diarrhetic shellfish poisoning. Tetrahedron Lett. 1987, 28, 5869-5872.

18. Lee, J.-S.; Tangen, K.; Dahl, E.; Hovgaard, P.; Yasumoto, T. Diarrhetic shellfish toxins in Norwegian mussels. Nippon Suisan Gakkaishi/Bull. Jap. Soc. Sci. Fish 1988, 54, 1953-1957.

19. Ciminiello, P.; Fattorusso, E.; Forino, M.; Magno, S.; Poletti, R.; Satake, M.; Viviani, R.; Yasumoto, T. Yessotoxin in mussels of the northern Adriatic Sea. Toxicon 1997, 35, 177-183.

20. Yasumoto, T.; Takizawa, A. Fluorometric measurement of yessotoxins in shellfish by highpressure liquid chromatography. Biosci. Biotechnol. Biochem. 1997, 61, 1775-1777.

21. Arévalo, F.; Pazos, Y.; Correa, J.; Salgado, C.; Moroño, A.; Paz, B.; Franco, J. M. First report of yessotoxins in mussels of Galician Rías during a bloom of Lingulodinium polyedra Stein (Dodge). In: Henshilwood, K., Deegan, B., McMahon, T., Cusack, C., Keaveney, S., Silke, J., O'Cinneide, M., Lyons, D., Hess, P., ed. Galway, Ireland, 2006, 184-189.

22. Vershinin, A.; Moruchkov, A.; Morton, S. L.; Leighfield, T. A.; Quilliam, M. A.; Ramsdell, J. S. Phytoplankton composition of the Kandalaksha Gulf, Russian White Sea: Dinophysis and lipophilic toxins in the blue mussel (Mytilus edulis). Harmful Algae 2006, 5, 558-564.

23. Morton, S. L.; Vershinin, A.; Leighfield, T. A.; Smith, L.; Quilliam, M. Identification of yessotoxin in mussels from the Caucasian Black Sea Coast of the Russian Federation. Toxicon 2007, 50, 581-584.

24. Satake, M.; Ichimura, T.; Sekiguchi, K.; Yoshimatsu, S.; Oshima, Y. Confirmation of yessotoxin and 45,46,47-trinoryessotoxin production by Protoceratium reticulatum collected in Japan. Nat. Toxins 1999, 7, 147-150.

25. Stobo, L. A.; Lewis, J.; Quilliam, M. A.; Hardstaff, W. R.; Gallacher, S.; Webster, L.; Smith, E.; McKenzie, M. Detection of yessotoxin in UK and Canadian isolates of phytoplankton and optimization and validation of LC-MS methods. In: Bates, S., ed. Gulf Fisheries Centre, Moncton, New Brunswick, Canada, 2003, 8-14. 
26. Samdal, I.A.; Naustvoll, L.J.; Olseng, C.D.; Briggs, L.R.; Miles, C.O. Use of ELISA to identify Protoceratium reticulatum as a source of yessotoxin in Norway. Toxicon 2004, 44, 75-82.

27. Paz, B.; Riobó, P.; Fernández, M. L.; Fraga, S.; Franco, J. M. Production and release of yessotoxins by the dinoflagellates Protoceratium reticulatum and Lingulodinium polyedrum in culture. Toxicon 2004, 44, 251-258.

28. Draisci, R.; Ferretti, E.; Palleschi, L.; Marchiafava, C.; Poletti, R.; Milandri, A.; Ceredi, A.; Pompei, M. High levels of yessotoxin in mussels and presence of yessotoxin and homoyessotoxin in dinoflagellates of the Adriatic Sea. Toxicon 1999, 37, 1187-1193.

29. Boni, L.; Ceredi, A.; Guerrini, F.; Milandri, A.; Pistocchi, R.; Poletti, R.; Pompei, M. Toxic Protoceratium reticulatum (Peridiniales, dinophyta) in the North-Western Adriatic Sea (Italy). In: Hallegraeff, G. M.; Blackburn, S. I.; Bolch, C. J.; Lewis, R. J., eds. Harmful Algal Blooms 2000: IOC of UNESCO, 2001, 137-140.

30. Ramstad, H.; Hovgaard, P.; Yasumoto, T.; Larsen, S.; Aune, T. Monthly variations in diarrhetic toxins and yessotoxin in shellfish from coast to the inner part of the Sognefjord, Norway. Toxicon 2001, 39, 1035-1043.

31. Armstrong, M.; Kudela, R. Evaluation of California isolates of Lingulodinium poliedrum for the production of yessotoxin. Afr. J. Mar. Sci. 2006, 25, 399-401.

32. Holmes, M. J.; Lewis, R. J.; Jones, A.; Wong Hoy, A. W. Cooliatoxin, the first toxin from Coolia monotis (Dinophyceae). Nat. Toxins 1995, 3, 355-362.

33. Daiguji, M.; Satake, M.; Ramstad, H.; Aune, T.; Naoki, H.; Yasumoto, T. Structure and fluorometric HPLC determination of 1-desulfoyessotoxin, a new yessotoxin analog isolated from mussels from Norway. Nat. Toxins 1998, 6, 235-239.

34. Rhodes, L.; McNabb, P.; de Salas, M.; Briggs, L.; Beuzenberg, V.; Gladstone, M. Yessotoxin production by Gonyaulax spinifera. Harmful Algae 2006, 5, 148-155.

35. Hansen, G.; Moestrup, Ø.; Roberts, K. R. Light and Electron Microscopical observations on Protoceratium reticulatum (Dinophyceae). Arch. Protistenkd. 1996-97, 147, 381-391.

36. Mackenzie, L.; Suzuki, T.; Adamson, J. Elimination and differential transformation of yessotoxin by the greenshell mussel Perna canaliculus and the blue mussel Mytilus gallopovincialis. In: Hallegraeff, G. M.; Blackburn, S. I.; Bolch, C. J.; Lewis, R. J., eds. Harmful Algal Blooms 2000: IOC of UNESCO, 2001, 371-374.

37. Franchini, A.; Milandri, A.; Poletti, R.; Ottaviani, E. Inmunolocalization of yessotoxins in the mussel Mytilus galloprovincialis. Toxicon 2003, 41, 967-970.

38. Poupin, J.; Cussatlegras, A.-S.; Geistdoerfer, P. Plancton Marin Bioluminescent. Inventaire documenté des espèces et bilan des formes les plus communes de la mer d'Iroise. In, Laboratoire d'Océanographie de l'École Navale, LOEN Lanvéoc-Poulmic, France, 1999, 1-83.

39. Rodríguez, J. J. G.; Mirón, A. S.; Belarbi, E. H.; García, M. C. C.; Camacho, F. G.; Grima, E. M. New culture approaches for yessotoxin production from the dinoflagellate Protoceratium reticulatum. Biotechnol. Prog. 2007, 23, 339-350.

40. Lewis, J.; Hallet, R. Lingulodinium polyedrum (Gonyaulax polyedra) a blooming dinoflagellate. Oceanogr. Mar. Biol., Annu. Rev. 1997, 35, 97-161.

41. Latz, M. I.; Rohr, J. Luminiscent response of the red tide dinoflagellates Lingulodinium polyedrum to laminar and turbulent flow. Limnology and Oceanography 1999, 44, 1423-1435. 
42. Lewis, J.; Burton, P. A study of newly excysted cells of Gonyaulax poyedra (Dinophyceae) by electron microscopy. Br. phycol. J. 1988, 23, 49-60.

43. Figueroa, R. I.; Bravo, I. Sexual reproduction and two different encystment strategies of Lingulodinium polyedrum (Dinophyceae) in culture. Journal of Phycology 2005, 41, 370-379.

44. Hansen, G.; Moestrup, O.; Roberts, K. R. Fine structural observations on Gonyaulax spinifera (Dinophyceae), with special emphasis on the flagellar apparatus. Phycologia 1996, 354-366.

45. Steidinger, K.; Tangen, K. Dinoflagellates. San Diego. Academic Press, 1996, 387-598.

46. Wall, D.; Dale, B. Modern dinoflagellate cysts and evolution of the Peridiniales. Micropaleontology 1968, 14, 265-304.

47. Dale, B. Dinoflagellate resting cysts: benthic plankton. In: Fryxell, G. A., ed. Survival strategies of the algae. Cambridge: Cambridge Univ. Press, 1983, 69-136.

48. Guerrini, F.; Ciminiello, P.; Dell-Aversano, C.; Tartaglione, L.; Fattorusso, E.; Boni, L.; Pistocchi, R. Influence of temperature, salinity and nutrient limitation on yessotoxin production and release by the dinoflagellate Protocetatium reticulatum in batch-cultures. Harmful Algae 2007, 6, 707-717.

49. Miles, C. O.; Samdal, I. A.; Aasen, J. A. G.; Jensen, D. J.; Quilliam, M. A.; Petersen, D.; Briggs, L. R.; Wilkins, A. L.; Rise, F.; Cooney, J. M.; MacKenzie, L. Evidence for numerous analogs of Yessotoxin in Protoceratium reticulatum. Harmful Algae 2005, 4, 1075-1091.

50. Satake, M.; Terasawa, K.; Kadowaki, Y.; Yasumoto, T. Relative configuration of YTX and isolation of two new analogs from toxic scallops. Tetrahedron Lett. 1996, 37, 5955-5958.

51. Ciminiello, P.; Fattorusso, E.; Forino, M.; Poletti, R.; Viviani, R. A new analogue of yessotoxin, carboxyyessotoxin, isolated from Adriatic Sea mussels. Eur. J. Org. Chem. 2000, 291-295.

52. Yasumoto, T.; Murata, M.; Lee, J. S.; Torigoe, K. Polyether toxins produced by dinoflagellates. Amsterdam: Elsevier, 1989, 375-382.

53. Satake, M.; Eiki, K.; Ichimura, T.; Ota, S.; Sekiguchi, K.; Oshima, Y. Structure of 45,46,47trinorhomoyessotoxin, a new yessotoxin analog, from Protoceratium reticulatum which represents the first detection of a homoyessotoxin analog in Japan. Harmful Algae 2006, 5, 731-735.

54. Satake, M.; Tubaro, A.; Lee, J. S.; Yasumoto, T. Two new analogs of yessotoxin, homoyessotoxin and 45-hydroxyhomoyessotoxin, isolated from mussels of the Adriatic Sea. Nat. Toxins 1997, 5, 107-110.

55. Ciminiello, P.; Fattorusso, E.; Forino, M.; Poletti, R.; Viviani, R. Structure determination of carboxyhomoyessotoxin, a new yessotoxin analogue isolated from adriatic mussels. Chem. Res. Toxicol. 2000, 13, 770-774.

56. Aasen, J.; Samdal, I. A.; Miles, C. O.; Dahl, E.; Briggs, L. R.; Aune, T. Yessotoxins in Norwegian blue mussels (Mytilus edulis): uptake from Protoceratium reticulatum, metabolism and depuration. Toxicon 2005, 45, 265-272.

57. Ciminiello, P.; Dell-Aversano, C.; Fattorusso, E.; Forino, M.; Magno, S.; Poletti, R. The detection and identification of 42,43,44,45,46,47,55-heptanor-41-oxoyessotoxin, a new marine toxin from adriatic shellfish, by liquid chromatography-mass spectrometry. Chem. Res. Toxicol. 2002, 15, 979-984. 
58. Ciminiello, P.; Fattorusso, E.; Forino, M.; Poletti, R. 42,43,44,45,46,47,55-Heptanor-41oxohomoyessotoxin, a new biotoxin from mussels of the northern Adriatic sea. Chem. Res. Toxicol. 2001, 14, 596-599.

59. Miles, C. O.; Wilkins, A. L.; Hawkes, A. D.; Selwood, A.; Jensen, D. J.; Aasen, J.; Munday, R.; Samdal, I. A.; Briggs, L. R.; Beuzenberg, V.; MacKenzie, A. L. Isolation of a 1,3-enone isomer of heptanor-41-oxoyessotoxin from Protoceratium reticulatum cultures. Toxicon 2004, 44, 325-336.

60. Miles, C. O.; Wilkins, A. L.; Jensen, D. J.; Cooney, J. M.; Quilliam, M. A.; Aasen, J.; MacKenzie, A. L. Isolation of 41a-Homoyessotoxin and the identification of 9-Methyl-41ahomoyessotoxin and Nor-ring-A-yessotoxin from Protoceratium reticulatum. Chem. Res. Toxicol. 2004, 17, 1414-1422.

61. Miles, C. O.; Wilkins, A. L.; Hawkes, A. D.; Selwood, A.; Jensen, D. J.; Munday, R.; Cooney, J. M.; Beuzenberg, V. Polyhydroxilated amide analogs of yessotoxin from Protoceratium reticulatum. Toxicon 2005, 45, 61-71.

62. Finch, S. C.; Wilkins, A. L.; Hawkes, A. D.; Jensen, D. J.; MacKenzie, L.; Beuzenberg, V.; Quilliam, M. A.; Olseng, C. D.; Samdal, I. A.; Aasen, J. A. G.; Selwood, A. I.; Cooney, J. M.; Sandvik, M.; Miles, C. O. Isolation and identification of (44- $R, S)-44,55$-dihydroxyyessotoxin from Protoceratium reticulatum, and its occurrence in extracts of shellfish from New Zealand, Norway and Canada. Toxicon 2005, 46, 160-170.

63. Souto, M. L.; Fernandez, J. J.; Franco, J. M.; Paz, B.; Gil, L. V.; Norte, M. Glycoyessotoxin A, a new yessotoxin derivate from cultures of Protoceratium reticulatum. J. Nat. Prod. 2005, 68, 420-422.

64. Miles, C. O.; Wilkins, A. L.; Selwood, A. I.; Hawkes, A. D.; Jensen, D. J.; Cooney, J. M.; Beuzenberg, V.; MacKenzie, A. L. Isolation of Yessotoxin 32-O-[ß-1-arabinofuranosyl-(5'-1")ß-1-arabinofuranoside] from Protoceratium reticulatum. Toxicon 2006, 47, 510-516.

65. Mitrovic, S. M.; Hamilton, B.; McKenzie, L.; Furey, A.; James, K. J. Persistence of yessotoxin under light and dark conditions. Mar. Environ. Res. 2005, 60, 397-401.

66. Ciminiello, P.; Fattorusso, E.; Forino, M.; Magno, S.; Poletti, R.; Viviani, R. Isolation of Adriatoxin, a New Analogue of Yessotoxin from Mussels of the Adriatic Sea. Tetrahedron Lett. 1998, 39, 8897-8900.

67. MacKenzie, L.; Holland, P.; McNabb, P.; Beuzenberg, V.; Selwood, A.; Suzuki, T. Complex toxin profiles in phytoplankton and Greenshell mussels (Perna canaliculus), revealed by LCMS/MS analysis. Toxicon 2002, 40, 1321-1330.

68. Samdal, I. A.; Aasen, J. A. G.; Briggs, L. R.; Dahl, E.; Miles, C. O. Comparison of ELISA and LC-MS analyses for yessotoxins in blue mussels (Mytilus edulis). Toxicon 2005, 46, 7-15.

69. Samdal, I. A. Yessotoxins in algae and mussels -Studies on its sources, disposition, and levels. In: Oslo, Norwegian School of Veterinary Science, 2005, 53.

70. Satake, M. Biosynthesis of the marine polyether toxin, yessotoxin. Tenner Yuki Kagobutsu Toronkay Koen Yoshishu 2000, 42, 259-264.

71. Nakanishi, K. The chemistry of brevetoxins: A review. Toxicon 1985, 23, 473-479.

72. Vilotijevic, I.; Jamison, T. F. Epoxide-Opening cascades promoted by water. Science 2007, 317, 1189-1192. 
73. Terao, K.; Ito, E.; Oarada, M.; Murata, M.; Yasumoto, T. Histopatological studies on experimental marine toxin poisoning-5. The effects in mice of yessotoxin isolated from Patinopecten yessoensis and of a desulfated derivate. Toxicon 1990, 28, 1095-1104.

74. Satake, M.; MacKenzie, L.; Yasumoto, T. Identification of Protoceratium reticulatum as the biogenetic origin of yessotoxin. Nat. Toxins 1997, 5, 164-167.

75. Suárez-Korsnes, M.; Hetland, D. L.; Espenes, A.; Tranulis, M. A.; Aune, T. Apoptotic events induced by yessotoxin in myoblast cell lines from rat and mouse. Toxicol. in Vitro 2006, 20, 1077-1087.

76. Franchini, A.; Marchesini, E.; Poletti, R.; Ottaviani, E. Acute toxic effect of the algal yessotoxin on Purkinje cells from the cerebellum of Swiss CD1 mice. Toxicon 2004, 43, 347352.

77. Franchini, A.; Marchesini, E.; Poletti, R.; Ottaviani, E. Lethal and sub-lethal yessotoxin dose induced morpho-functional alterations in intraperitoneal injected Swiss CD1 mice. Toxicon 2004, 44, 83-90.

78. Franchini, A.; Marchesini, E.; Poletti, R.; Ottaviani, E. Swiss mice CD1 fed on mussels contaminated by okadaic acid and yessotoxins: effects on thymus and spleen. Eur. J. Histochem. 2005, 49, 179-188.

79. Tubaro, A.; Sosa, S.; Altinier, G.; Soranzo, M. R.; Satake, M.; Loggia, R. D.; Yasumoto, T. Short-term oral toxicity of homoyessotoxins, yessotoxin and okadaic acid in mice. Toxicon 2004, 43, 439-445.

80. De la Rosa, L. A.; Alfonso, A.; Vilariño, N.; Vieytes, M. R.; Botana, L. M. Modulation of cytosolic calcium levels of human lymphocytes by yessotoxin, a novel marine phycotoxin. Biochem. Pharmacol. 2001, 61, 827-833.

81. De la Rosa, L. A.; Alfonso, A.; Vilariño, N.; Vieytes, M. R.; Yasumoto, T.; Botana, L. M. Maitotoxin-induced calcium entry in human lymphocytes modulation by yessotoxin, $\mathrm{Ca}^{2+}$ channel blockers and kinases. Cellular Signalling 2001, 12, 711-716.

82. Alfonso, A.; de la Rosa, L. A.; Vieytes, M. R.; Yasumoto, T.; Botana, L. M. Yessotoxin, a novel phycotoxin, activates phosphodiesterase activity. Effect of yessotoxin on cAMP levels in human lymphocytes. Biochem. Pharmacol. 2003, 65, 193-208.

83. Pazos, M. J.; Alfonso, A.; Vieytes, M. R.; Yasumoto, T.; Botana, L. M. Kinetic Analysis of the Interaction between Yessotoxin and Analogues and Immobilized Phosphodiesterases Using a Resonant Mirror Optical Biosensor. Chem. Res. Toxicol. 2005, 18, 1155-1160.

84. Pazos, M.-J.; Alfonso, A.; Vieytes, M. R.; Yasumoto, T.; Botana, L. M. Study of the Interaction between Different Phosphodiesterases and Yessotoxin Using a Resonant Mirror Biosensor. Chem. Res. Toxicol. 2006, 19, 794-800.

85. Leira, F.; Alvarez, C.; Vieites, J. M.; Vieytes, M. R.; Botana, L. M. Characterization of distinct apoptotic changes induced by okadaic acid and yessotoxin in the BE(2)-M17 neuroblastoma cell line. Toxinol. in Vitro 2002, 16, 23-31.

86. Malaguti, C.; Ciminiello, P.; Fattorusso, E.; Rossini, G. P. Caspase activation and death induced by yessotoxin in HeLa cells. Toxicol. in Vitro 2002, 16, 357-363. 
87. Suárez-Korsnes, M.; Hetland, D. L.; Espenes, A.; Aune, T. Induction of apoptosis by YTX in myoblast cell lines via mitochondrial signalling transduction pathway. Toxicol. in Vitro 2006, 20, 1419-1426.

88. Suárez-Korsnes, M.; Hetland, D. L.; Espenes, A.; Aune, T. Cleavage of tensin during cytoskeleton disruption in YTX-induced apoptosis. Toxicol. in Vitro 2007, 21, 9-15.

89. Ronzitti, G.; Callegari, F.; Malaguti, C.; Rossini, G. P. Selective disruption of the E-cadherincatenin system by an algal toxin. Br. J. Cancer 2004, 90, 1100-1107.

90. Malagoli, D.; Ottaviani, E. Yessotoxin affects fMLP-induced cell shape changes in Mytilus galloprovincialis immunocytes. Cell Biol. Int. 2004, 28, 57-61.

91. Malagoli, D.; Casarini, L.; Ottaviani, E. Algal toxin yessotoxin signalling pathways involve immunocyte mussel calcium channels. Cell Biol. Int. 2006, 30, 721-726.

92. Malagoli, D.; Marchesini, E.; Ottaviani, E. Lysosomes as the target of yessotoxin in invertebrate and vertebrate cell lines. Toxicol. Lett. 2006, 167, 75-83.

93. Ferrari, S.; Ciminiello, P.; Dell-Aversano, C.; Forino, M.; Malaguti, C.; Tubaro, A.; Poletti, R.; Yasumoto, T.; Fattorusso, E.; Rossini, G. P. Structure-Activity relationships of yessotoxins in cultured cells. Chem. Res. Toxicol. 2004, 17, 1251-1257.

94. Yasumoto, T.; Oshima, Y.; Yamaguchi, M. Occurrence of a new type of shellfish poisoning in the Tohoku district. Bull. Jpn. Soc. Sci. Fish. 1978, 44, 1249-1255.

95. Yasumoto, T.; Murata, M.; Oshima, Y.; Matsumoto, G. K.; Clardy, J. Diarrhetic Shellfish Toxins. In: Ragelis, E. P., ed. Seafood toxins. Washington, D. C.: American Chemical Society, 1984, 207-214.

96. EC. Commision Regulation No 2074/2005 of 5 December 2005, laying down implementing measures for certain products under Regulation (EC) No 853/2004 of the European Parliament and of the Council and for the organisation of official controls under Regulation (EC) $\mathrm{N}^{\mathrm{o}}$ $854 / 2004$ of the European Parliament and of the Council and Regulation (EC) No 882/2004 of the European Parliament and of the Council, derogating from Regulation (EC) No 852/2004 of the European Parliament and of the Council and amending Regulations (EC) $N^{\circ} 853 / 2004$ and (EC) $\mathrm{N}^{\mathrm{o}}$ 854/2004. Official Journal of the European Union 2005, L 338, p. 27.

97. Stabell, O. B.; Steffenak, I.; Pedersen, K.; Underdal, B. Diversity of shellfish toxins of "diarrhetic" type revealed by biological and chemical assays. J. Toxicol. Environ. Health 1991, 33, 273-282.

98. Suzuki, T.; Jin, T.; Shirota, Y.; Mitsuya, T.; Okomura, Y.; Kamiyama, T. Quantification of lipophilic toxins associated with diarrhetic shellfish poisoning in Japanese bivalves by liquid chromatography-mass spectrometry and comparison with mouse bioassay. Fish Sci. 2005, 71, 1370-1378.

99. Hess, P.; McMahon, T.; Slattery, D.; Swords, D. D., G.; McCarron, M.; Clarke, D.; Gibbons, W.; Silke, J.; O'Cinneide, M. Use of LC-MS texting to identify lipophilic toxins, to establish local trends and interspecies differences and to test the comparability of LC-MS testing with the mouse bioassay: an example from the Irish biotoxin monitoring programme 2001. In: Villalba, A.; Reguera, B.; Romalde, J. L.; Beiras, R., eds. Molluscan Shellfish Safety. Santiago de Compostela: Consellería de Pesca, Xunta de Galicia and IOC of UNESCO, 2003, 57-66. 
100. Hess, P.; Grune, B.; Anderson, D. B.; Aune, T.; Botana, L. M.; Caricato, P.; Egmond, H. P. v.; Halder, M.; Hall, S.; Lawrence, J. F.; Moffat, C.; Poletti, R.; Richmond, J.; Rossini, G. P.; Seamer, C.; Vilageliu, J. S. Three Rs approaches in marine biotoxin testing. ATLA: Alternatives to Laboratory Animals 2006, 36, 193-224.

101. Aune, T.; Yasumoto, T.; Engeland, E. Light and scanning electron microscopic studies on effects of marine algal toxins toward freshly prepared hepatocytes. J. Toxicol. Environ. Health. 1991, 34, 1-9.

102. Pierotti, S.; Malaguti, C.; Milandri, A.; Poletti, R.; Rossini, G. P. Functional assay to measure yessotoxins in contaminated mussel samples. Anal. Biochem. 2003, 312, 208-216.

103. Pierotti, S.; Albano, C.; Milandri, A.; Callegari, F.; Poletti, R.; Rossini, G. P. A slot blot procedure for the measurement of yessotoxins by a functional assay. Toxicon 2007, 49, 36-45.

104. Pazos, M. J.; Alfonso, A.; Vieytes, M. R.; Yasumoto, T.; Vieites, J. M.; Botana, L. M. Resonant mirror biosensor detection method based on yessotoxin-phosphodiesterase interactions. Anal. Biochem. 2004, 335, 112-118.

105. Briggs, L. R.; Miles, C. O.; Fitzgerald, J. M.; Ross, K. M.; Garthwaite, I.; Towers, N. R. Enzyme-linked immunosorbent assay for the detection of yessotoxin and its analogues. $J$ Agric Food Chem. 2004, 52, 5836-5842.

106. Kleivdal, H.; Briggs, L.; Miles, C. O. Development and validation of YTX ELISA-a rapid assay for the determination of yessotoxin in shellfish and environmental samples. In: Baiona, Spain, 2005, 53.

107. Ramstad, H.; Larsen, S.; Aune, T. Repeatability and validity of a fluorimetric HPLC method in the quantification of yessotoxin in blue mussels (Mytilus edulis) related to the mouse bioassay. Toxicon 2001, 39, 1393-1397.

108. Paz, B.; Riobó, P.; Souto, M. L.; Gil, L. V.; Norte, M.; Fernandez, J. J.; Franco, J. M. Detection and identification of glycoyessotoxin $\mathrm{A}$ in a culture of the dinoflagellate Protoceratium reticulatum. Toxicon 2006, 48, 611-619.

109. Stobo, L. A.; Lacaze, J. P.; Scott, A. C.; Gallacher, S.; Smith, E. A.; Quilliam, M. A. Liquid chromatography with mass spectrometry-detection of lipophilic shellfish toxins. J. AOAC Int. 2005, 88, 1371-1382.

110. Draisci, R.; Giannetti, L.; Lucentini, L.; Ferretti, E.; Palleschi, L.; Marchiafava, C. Direct identification of yessotoxin in shellfish by liquid chromatography coupled with mass spectrometry and tandem mass spectrometry. Rapid Commun. Mass Spectrom. 1998, 12, 12911296.

111. Ciminiello, P.; Dell-Aversano, C.; Fattorusso, E.; Forino, M.; Magno, S.; Poletti, R. Direct detection of yessotoxin and its analogues by liquid chromatography coupled with electrospray ion trap mass spectrometry. J. Chromatogr. A 2002, 968, 61-69.

112. Cooney, J.M.; Jensen, D.J.; Miles, C.O. Ion-trap LC-MS as a tool for structural characterisation of matrine algal toxins. In: Cawthron Institute, P. R., New Zealand, ed., 2003, 59-64.

113. Draisci, R.; Palleschi, L.; Giannetti, L.; Lucentini, L.; James, K. J.; Bishop, A. G.; Satake, M.; Yasumoto, T. New approach to the direct detection of known and new diarrhoeic shellfish toxins in mussels and phytoplankton by liquid chromatography-mass spectrometry. $J$. Chromatogr. A 1999, 847, 213-221. 
114. Fernandez-Amandi, M.; Furey, A.; Lehane, M.; Ramstad, H.; James, K. J. Liquid chromatography with electrospray ion-trap mass spectrometry for the determination of yessotoxins in shellfish. J. Chromatogr. A 2002, 976, 329-334.

115. Goto, H.; Igarashi, T.; Yamamoto, M.; Yasuda, M.; Sekiguchi, R.; Watai, M.; Tanno, K.; Yasumoto, T. Quantitative determination of marine toxins associated with diarrhetic shellfish poisoning by liquid chromatography coupled with mass spectrometry. J. Chromatogr. A 2001, 907, 181-189.

116. Fux, E.; McMillan, D.; Bire, R.; Hess, P. Development of an ultra-performance liquid chromatography.mass spectrometry method for the detection of lipophilic marine toxins. $J$. Chromatogr. A 2007, 1157, 273-280.

117. De la Iglesia, P.; Gago-Martinez, A.; Yasumoto, T. Advanced studies for the application of high performance capillary electrophoresis for the analysis of yessotoxin and 45hydroxyyessotoxin. J. Chromatogr. A 2007, 1156, 160-166.

118. EC. Commission Decision 2002/225/EC of 15 March 2002 laying down detailed rules for the implementation of Council Directive 91/492/EEC as regards the maximum levels and the methods of analysis of certain marine biotoxins in bivalve molluscs, echinoderms, tunicates and marine gastropods. Official Journal of the European Communities 2002, p. 62.

(C) 2008 by the author(s); licensee Molecular Diversity Preservation International, Basel, Switzerland. This article is an open-access article distributed under the terms and conditions of the Creative Commons Attribution license (http://creativecommons.org/licenses/by/3.0/). 